\title{
The role of potassium ions in iron hexacyanoferrate as a cathode material for hybrid ion batteries
}

\author{
Jia-Ying Liao, Qiao Hu, Bang-Kun Zou, Jun-Xiang Xiang, Chun-Hua Chen*
}

CAS Key Laboratory of Materials for Energy Conversions, Department of Materials Science and Engineering \& Collaborative Innovation Center of Suzhou Nano Science and Technology, University of Science and Technology of China, Hefei 230026, Anhui, China

\begin{abstract}
The synthesis of $\mathrm{Na}_{\mathrm{x}} \mathrm{K}_{\mathrm{y}} \mathrm{Fe}\left[\mathrm{Fe}(\mathrm{CN})_{6}\right]$ through a simple co-precipitation method and the application of these nanoparticles in sodium-ion batteries are presented. $\mathrm{K}_{1.90} \mathrm{Fe}\left[\mathrm{Fe}(\mathrm{CN})_{6}\right]$ with a cubic structure shows low volumetric change during electrochemical cycling. It is clarified by ex-situ X-ray diffraction and cyclic voltammetry curves that $\mathrm{K}^{+}$influences the intercalation sites of the neighboring $\mathrm{Na}^{+}$. More significantly, this hexacyanoferrate delivers a high capacity of 137.0 $\mathrm{mAh} \mathrm{g}^{-1}$ at a current density of $14 \mathrm{~mA} \mathrm{~g}^{-1}$ and superior cyclability with $94 \%$ capacity retention after 120 cycles, showing great promise for sodium-ion battery applications.
\end{abstract}

Keywords: potassium; iron hexacyanoferrate; interstitial site; phase transition; sodium-ion batteries.

Corresponding authors: E-mail: cchchen@ustc.edu.cn; Phone: +86-551-63606971; Fax: (+86)551-63601592. 


\section{Introduction}

Recently, prussian blue analogues (PBAs): $\mathrm{A}_{2-\mathrm{x}} \mathrm{M}_{\mathrm{a}}\left[\mathrm{M}_{\mathrm{b}}(\mathrm{CN})_{6}\right]_{1-\mathrm{y}} \cdot \mathrm{zH}_{2} \mathrm{O}$ (A: alkali cations, M: metal ions) have attracted much attention as cathode materials for secondary batteries, due to their special structure that support a reversible extraction of $\mathrm{Li}^{+}, \mathrm{Na}^{+}$and $\mathrm{K}^{+}$ions [1-5], especially for the sodium-ion batteries (SIB) in terms of low cost and resource abundance. For instance, You et al. has demonstrated $\mathrm{Na}_{0.84} \mathrm{Ni}\left[\mathrm{Fe}^{\mathrm{II}}(\mathrm{CN})_{6}\right]_{0.71}$ as a zero-strain insertion cathode material with an excellent cycling stability [6]. High-quality $\mathrm{Na}_{0.61} \mathrm{Fe}\left[\mathrm{Fe}(\mathrm{CN})_{6}\right]_{0.94}$ crystals show excellent electrochemical properties as a cathode of SIB, yet an initial sodium insertion process is needed due to the low sodium content [7]. Lee et al. have demonstrated sodium manganese hexacyanomanganate $\left(\mathrm{Na}_{1.96} \mathrm{Mn}^{\mathrm{II}}\left[\mathrm{Mn}^{\mathrm{II}}(\mathrm{CN})_{6}\right]_{0.99}\right)$ with extremely high capacity ( 209 $\left.\mathrm{mAh} \mathrm{g}^{-1}\right)$ [8]. Wang et al. has synthesized rhombohedral prussian white $\left(\mathrm{Na}_{1.92} \mathrm{Fe}\left[\mathrm{Fe}(\mathrm{CN})_{6}\right]\right)$ with few vacancies that delivers high specific capacity and good rate performance, which can be partly attributed to the high Na concentration [9]. On the other hand, these sodium-rich materials usually suffer from obvious capacity fading during the first ten cycles owing to the phase transition from monoclinic/rhombohedral to cubic structure during the $\mathrm{Na}^{+}$extraction $[6,10]$.

The phase transition occurs as the less covalent $\mathrm{M}_{\mathrm{a}}{ }^{\mathrm{II}}$ can accommodate a reduced bond angle $\angle \mathrm{M}_{\mathrm{b}}-\mathrm{CN}-\mathrm{M}_{\mathrm{a}}$ and minimize void space, when the size of insertion cation is relatively small [11]. For example, $\mathrm{A}_{2} \mathrm{Mn}^{\mathrm{II}}\left[\mathrm{Mn}^{\mathrm{II}}(\mathrm{CN})_{6}\right]$ with the lattice parameter about $10.6 \AA$, rhombohedral structure can be observed (A=Na, K, Rb) except for the cubic $\mathrm{Cs}_{2} \mathrm{Mn}^{\mathrm{II}}\left[\mathrm{Mn}^{\mathrm{II}}(\mathrm{CN})_{6}\right][11,12]$. Thus, the cubic-rhombohedral structural phase 
transition is related to the occupation of small cations at other interstitial positions (in the $<111>$ directions towards the four tetrahedral sites, 32f ) $[13,14]$. While the lattice parameter of iron hexacyanoferrate $(\mathrm{FeHCF})$ is smaller $(\sim 10.18 \AA)$ [15], Ling et al. have calculated that the most stable $\mathrm{Na}^{+}$interstitial site in $\mathrm{Fe}\left[\mathrm{Fe}(\mathrm{CN})_{6}\right]$ is face-centered site (24d). As for large cations such as $\mathrm{K}^{+}, \mathrm{Rb}^{+}$and $\mathrm{Cs}^{+}$, they usually prefer to occupy the body-center (8c) site of the empty cube. Even more, the large space of $8 \mathrm{c}$ site is capable of accommodating the insertion of $\mathrm{K}^{+}$without too much structural deformation [16]. Liu et al. have also suggested that multiple $\mathrm{Na}^{+}$ intercalation sites can be confirmed in the Na-rich $\mathrm{Na}_{x} \mathrm{Fe}\left[\mathrm{Fe}(\mathrm{CN})_{6}\right] ; \mathrm{Na}^{+}$may intercalate into $8 \mathrm{c}$ site or $24 \mathrm{~d}$ site, which leads to bizarre charge/discharge curves [17].

The co-intercalations of alkali and alkaline earth cations such as $\mathrm{Mg}-\mathrm{Li}$ [18], $\mathrm{Mg}-\mathrm{Na}$ [19], have been reported in literature. However, it is difficult to synthesize $\mathrm{MgFeHCF}$ through a precursor-based method. Instead, it is obtained via an electrochemical way in which $\mathrm{Mg}^{2+}$ ions are introduced from electrolyte or $\mathrm{Mg}$ counter electrode during a discharge process. Moreover, the average voltage of a $\mathrm{MgFeHCF}$ electrode is usually less than $3.0 \mathrm{~V}$. In this paper, alkali iron hexacyanoferrates with different contents of sodium and potassium $\left(\mathrm{Na}_{\mathrm{x}} \mathrm{K}_{\mathrm{y}} \mathrm{FeHCF}\right)$ are synthesized via a co-precipitation method. The FeHCF with an average voltage of about $3.3 \mathrm{~V}$ shows an interesting cation selectivity $\left(\mathrm{K}^{+}>\mathrm{Na}^{+}\right)$so that $\mathrm{K}^{+}$in the electrolyte can reinsert into the structure during the electrochemical cycling despite of its low concentration. Also, its charge/discharge curves and cycling performance are found to be improved with $\mathrm{K}^{+}$in the structure. 


\section{Experimental}

\subsection{Materials synthesis}

Synthesis of $\mathrm{Na}_{\mathrm{x}} \mathrm{K}_{\mathrm{y}} \mathrm{FeHCF}$ was carried out as described elsewhere in the literature by a typical co-precipitation method [17], with slight modification. Solution A: 5 mmol of $\mathrm{A}_{4} \mathrm{Fe}(\mathrm{CN})_{6}(\mathrm{~A}=\mathrm{Na}$ or $\mathrm{K})$ was dissolved in $100 \mathrm{~mL}$ of deionized water. Solution B: $5 \mathrm{mmol}$ of $\mathrm{FeCl}_{2}$ and $6.7 \mathrm{mmol}$ of sodium/potassium citrate were dissolved in $100 \mathrm{~mL}$ of deionized water, $0.5 \mathrm{~g}$ of ascorbic acid was used to avoid the oxidation of $\mathrm{Fe}^{2+}$. The solution A was slowly added into the solution $\mathrm{B}$ under vigorous stirring, and then maintained at room temperature for $10 \mathrm{~h}$. The molar ratios of Na:K were $0: 1,1: 1,3: 1,7: 1$ and 1:0, respectively, for both of the two precursor solutions. The products were washed for several times with deionized water and ethanol, and finally dried at $100{ }^{\circ} \mathrm{C}$ in a vacuum oven for $24 \mathrm{~h}$. The as-obtained products are marked as NKFF-X $(X=1,2,3,4,5)$, where $X$ increases along with the sodium content.

\subsection{Characterization}

The phase of as-obtained samples was characterized by an X-ray diffractometer (Philips X'Pert Pro Super, $\mathrm{Cu} \mathrm{K} \alpha$ radiation). The morphology of the samples was studied by scanning electron microscopy (SEM, Sirion 2000, FEI) and transmission electron microscope (TEM, H-800 Hitachi). The elemental compositions were analyzed by energy dispersive X-ray spectroscopy (EDS) attached to the SEM instrument. Thermogravimetric analysis (TGA) was performed at a heating rate of 
$10{ }^{\circ} \mathrm{C} \min ^{-1}$ in the temperature range of $30-700{ }^{\circ} \mathrm{C}$ under flowing $\mathrm{N}_{2}$ (DTG-60H, Shinadzu).

\subsection{Electrochemical evaluation}

The electrochemical properties of the obtained FeHCF materials were evaluated in coin-type cells (CR2032 size). The electrode laminates consisted of the active material (70 wt. \%), acetylene black (20 wt. \%) and PVDF (10 wt. \%) binder on an aluminium foil collector. The typical electrode mass was about $2 \mathrm{mg} \mathrm{cm}^{-2}$. For the fabrication of sodium half cells, sodium metal was used as the counter electrode and 1 mol L${ }^{-1} \mathrm{NaClO}_{4}$ in EC/DMC (1:1 in volume)/1\% FEC was used as the electrolyte. For lithium half cells, the sample NKFF-1 with the best Na half-cell performance was used as the working electrode, lithium foil as the counter electrode and $1 \mathrm{~mol} \mathrm{~L}^{-1}$ $\mathrm{LiPF}_{6}$ in EC/DEC (1:1 in volume) as the electrolyte. In both of the cells, a Whatman glass-fiber separator was used. The coin-cells were assembled in an argon-filled glove box $\left(\mathrm{O}_{2}\right.$ and $\mathrm{H}_{2} \mathrm{O}$ contents were 2 and $1 \mathrm{ppm}$, respectively), and then aged for $10 \mathrm{~h}$ before charge/discharge to ensure full infiltration of electrolyte into the electrodes. The cyclic voltammetry (CV) and electrochemical impedance spectroscopy (EIS) of the cells were conducted on a CHI 604A electrochemical workstation. The CV was measured in a voltage range from 2.0 to $4.2 \mathrm{~V}$ at a scan rate of $0.1 \mathrm{mV} \mathrm{s}^{-1}$. The cells were also galvanostatically cycled on a multi-channel battery test system (Neware BTS-2300, Shenzhen) in the voltage range from 2.0 to $4.2 \mathrm{~V}$.

\subsection{Ex-situ EDS}


$\mathrm{Na}$ half cells for ex-situ EDS measurements were specially-made. The NKFF-1 electrode mass was $1.91 \pm 0.03 \mathrm{mg}, 0.4 \mathrm{~mL} 1 \mathrm{~mol} \mathrm{~L}^{-1} \mathrm{NaClO}_{4}$ in EC/DMC $(1: 1$ in volume, without FEC) was used as the electrolyte (the molar ratio of $\mathrm{K}: \mathrm{Na}$ was about 1:40). The cells were charged and discharged at a low current of $14 \mathrm{~mA} \mathrm{~g}^{-1}$ (0.1 C) to a certain voltage, and then were disassembled and washed by DMC in the glove box.

\section{Results and discussion}

The initial color of the as-obtained samples is pale blue, while they slowly become darken during the washing process as a result of the oxidation of $\mathrm{Fe}^{\mathrm{II}}$ and $\mathrm{Na} / \mathrm{K}$ loss. The $(\mathrm{Na}+\mathrm{K})$ contents of freshly synthesized NKFF-X samples are expected theoretically to be $(\mathrm{Na}+\mathrm{K}) / \mathrm{Fe}=1$. However, if $\mathrm{Fe}^{\mathrm{II}}$ is gradually oxidized to $\mathrm{Fe}^{\mathrm{III}}$ when it is exposed to air, the same amount of alkali cation should be lost for the sake of charge neutrality. Table 1 shows the Na and K contents (molar) of NKFF-X samples obtained by EDS analysis, and all the metal contents are normalized to the Fe content. Obviously, the total alkali cation $(\mathrm{Na}+\mathrm{K})$ contents decrease from NKFF-1 to NKFF-5, which means the KFeHCF is more air-stable. And the K contents (NKFF-2, 3, 4) higher than expected can be attributed to the cation selectivity of FeHCF. The TEM images (Fig. 1a) show the samples are composed of nanoparticles with sizes of 20-40 nm. The samples with high $\mathrm{Na}$ contents (e.g. NKFF-5) possess a cubic-like morphology due to the strong chelating ability of citrate and slower precipitation rate $[17,20]$. HR-TEM images (Fig. 1c and 1d) show the lattice fringes of NKFF-1 and 
NKFF-5, in which (200) and (400) planes can be identified and the lattice parameter are about $10.1 \AA$ and $10.2 \AA$, respectively.

The XRD patterns of all the samples shown in Fig. 2a are readily indexed to the face-centered-cubic structure of prussian blue (JCPDS No: 52-1907). In accord with their morphology, the high $\mathrm{Na}$ content samples show better crystallinity. The expanded XRD patterns from $15^{\circ}$ to $20^{\circ}$ are shown in Fig. $2 \mathbf{b}$. The diffraction peaks slightly shift to the lower angles, indicating that the lattice parameter increases with sodium content, especially for the potassium-free sample (NKFF-5). The lattice parameter of the NKFF-1 sample is calculated to be $a=10.13 \AA$ (Fig. 2c), being close to the result of HR-TEM. It means the potassium ions prevent the volumetric expansion, and even slightly reduce the lattice parameter. Similar changes during the insertion of $\mathrm{K}^{+}$in $\mathrm{CuHCF}$ and FeHCF have been reported [4, 21-23]. Fig. 3 show the TG and DTA curves. The weight loss below $190^{\circ} \mathrm{C}$ can be assigned to the elimination of absorbed and/or interstitial waters [24]. The NKFF-1 sample shows the lowest water content (absorbed and interstitial water), due to the existence of relatively high content of alkali ions at interstitial site [22]. Nevertheless, some of NKFF samples (e.g. NKFF-5) start to decompose when the temperature reaches to about $160^{\circ} \mathrm{C}$, as confirmed by the change of DTA curves. The sharp weight loss occurring at about $300^{\circ} \mathrm{C}$ can be attributed to the decomposition of $\mathrm{NaKFeHCF}$ to $\mathrm{Fe}(\mathrm{CN})_{2}, \mathrm{CN}$ and $\mathrm{A}_{2} \mathrm{O}$ ( $\mathrm{A}=\mathrm{Na}$ or $\mathrm{K}$, the $\mathrm{O}$ atom comes from coordinated water) [25]. The last weight loss step occurring in the range of $500^{\circ} \mathrm{C}$ to $700^{\circ} \mathrm{C}$ due to the decomposition of $\mathrm{Fe}(\mathrm{CN})_{2}$ 
into $\mathrm{Fe}, \mathrm{C}$ and $\mathrm{N}_{2}$. Thus, the highest decomposition temperatures of NKFF-1measured here evidences its stable structure.

Fig. 4a and 4b compare the first and second charge/discharge profiles of NKFF-1 and NKFF-5 samples in a Na half-cell with a current density of $0.1 \mathrm{C}(1 \mathrm{C}=140 \mathrm{~mA}$ $\left.\mathrm{g}^{-1}\right)$. The charge/discharge curves of other samples are shown in Fig. S1, where the curves of NKFF-4 are close to that of Piernas-Muñoz's work [26]. The NKFF-1 sample delivers the highest initial charge capacity, due to its highest alkali cation content, while all the initial discharge capacity are close to $140 \mathrm{mAh} \mathrm{g}^{-1}$. Furthermore, the NKFF-1 electrode exhibits two plateaus, corresponding to the two kinds of $\mathrm{Fe}^{\mathrm{III}} / \mathrm{Fe}^{\mathrm{II}}$ (low-spin $\mathrm{FeC}_{6}$ and high-spin $\mathrm{FeN}_{6}$ ) redox reactions, respectively. The main CV curves (Fig. 4d) demonstrate two pairs of oxidation/redox peaks at 3.18/2.77 V $\left(\mathrm{Na}_{1} \leftrightarrow \mathrm{Na}_{2}\right)$ and 3.74/3.43 V $\left(\mathrm{Na}_{0} \leftrightarrow \mathrm{Na}_{1}\right)$ for NKFF-1, and a little deviation with the charge/discharge voltage plateaus is resulted from the polarization at a higher current density. The similar charge/discharge profiles are shown in other potassic samples (NKFF-2, 3, 4). However, the NKFF-5 electrode exhibits three uneven plateaus during the second charge process, clarified by the three oxidation peaks of CV curves. This peculiar double peak phenomenon at high voltage is a consequence of $\mathrm{Na}^{+}$ intercalation into both $8 \mathrm{c}$ and $24 \mathrm{~d}$ sites, and the calculated voltages to extract $\mathrm{Na}^{+}$ from these two sites are 3.72 and $4.15 \mathrm{~V}$, respectively [17]. As for potassic samples, the single peak at $3.74 \mathrm{~V}$ demonstrates that only $8 \mathrm{c}$ site is permitted when there is $\mathrm{K}^{+}$ neighboring (Fig. 4c). The higher voltage plateaus of $8 \mathrm{c}$ site and lower polarization of potassic samples increase the energy density. 
The reversible intercalation and de-intercalation of $\mathrm{K}^{+}$in NKFF-1 are directly proved by the ex-situ EDS analysis, which is consistent with the results of Piernas-Muñoz et al. [26]. As shown in Fig. 5c, the contents of $\mathrm{Na}+\mathrm{K}$ show an approximately linear change during the discharge/charge process (Fig. 5a). However, the $\mathrm{K}^{+}$is the dominant cation, opposite to the initial cation concentration in the electrolyte. The $\mathrm{K}^{+}$ratio of fully discharged electrode is 0.87 (obtained by ex-situ EDS), which means $92 \%$ of $\mathrm{K}^{+}$are remained. The cation selectivity $\left(\mathrm{K}^{+}>\mathrm{Na}^{+}>\mathrm{Li}^{+}\right)$ of PB in both of aqueous and propylene carbonate solutions have been demonstrated by Crumbliss et al [27]. This is in reverse order to ionic radius and in the order of increasing solvated radius $\left(\mathrm{K}^{+}, 2.75 \AA \mathrm{Aa}^{+}, 3.10 \AA \mathrm{A}^{+}, 3.37 \AA\right)[28]$ determined by ionic mobility, activation energy for interfacial charge transfer[29] and strong interaction with PB $[26,30]$. In addition, the detection limit of $\mathrm{K}^{+}$for some PBAs is below $1 \times 10^{-4} \mathrm{M}$, with the potentiometric selectivity coefficient of the potassium ion-selective electrode based on the CoHCF film-modified electrode is $2 \times 10^{-2}\left(K_{\mathrm{K}, \mathrm{Na}}^{\mathrm{pot}}\right)$ and $1 \times 10^{-3}\left(K_{\mathrm{K}, \mathrm{Li}}^{\mathrm{pot}}\right)$, respectively [31-33]. The selectivity coefficient $K_{\mathrm{K}, \mathrm{B}}^{\mathrm{pot}}$ is calculated from the following equation[34] recommended by IUPAC:

$$
K_{\mathrm{K}, \mathrm{B}}^{\mathrm{pot}}=a_{\mathrm{K}}\left(e^{\Delta E Z_{\mathrm{K}} F / R T}-1\right) /\left(a_{\mathrm{B}}\right)^{Z_{\mathrm{K}} / Z_{\mathrm{B}}}
$$

Therefore, the FeHCF supports a reversible extraction of $\mathrm{K}^{+}$in $\mathrm{Na}$ half cells, as a low concentration of $\mathrm{K}^{+}$in the electrolyte can reinsert into the structure. Nevertheless, there are some residual $\mathrm{K}^{+}$ions even the electrode is fully charged. It implies the $\mathrm{K}^{+}$ ions in FeHCF are two types: (i) the internal potassium ions, within the crystalline structure and (ii) the surface potassium ions [35]. Both internal and surface sites of 
FeHCF show cation selectivity, and the $\mathrm{Na}^{+}$at surface site is more unstable. Furthermore, one of the NKFF-1 electrodes was first charged and washed by DMC to complete internal $\mathrm{K}^{+}$extraction, and then reassembled. The charge/discharge profiles (Fig. S2) similar to NKFF-5 (without even plateaus) evidence the $\mathrm{K}^{+}$ions at surface sites are electrochemical inactive. Thus, the rapid variation of charge/discharge profiles of NKFF-4 (Fig. S1c) are related to increase of the residual $\mathrm{Na}$ and $\mathrm{K}$ contents of fully charged NKFF-4 during cycles (Fig. S3). It can be ascribed to the low concentration of internal $\mathrm{K}^{+}$gradually gathering at the surface (as shown in Fig. 6) and losing the effect. For other potassic samples, the surface sites are obviously not enough for all of the $\mathrm{K}^{+}$ions. Fig. 5b are ex-situ XRD patterns of NKFF-1 electrodes at various discharge and charge states. During the $\mathrm{K}^{+}$and $\mathrm{Na}^{+}$insertion process, the (200) peak intensity relative to that of the (220) peak decrease, together with the slight shift of the positions of XRD peaks toward bigger angle (decrease of the lattice parameter). This finding differs from the single $\mathrm{Na}^{+}$insertion process, where the lattice parameter increases and the crystal structure changes from cubic to rhombohedral $[7,15,17]$. The phase transition is suppressed, as $\mathrm{K}^{+}$ions are too large to move along the cubic [111] axis towards $32 \mathrm{f}$ site. The decrease of lattice parameter by $1.1 \%(10.23 \rightarrow 10.12 \AA$, Fig. 7$)$ is a combined effect of (i) a shortening of the $\mathrm{Fe}^{\mathrm{HS}}-\mathrm{N}$ bond distance and (ii) the extra electron introduced to the $\mathrm{Fe}^{\mathrm{LS}}-\mathrm{C}-\mathrm{N}-\mathrm{Fe}^{\mathrm{HS}} \pi$ bonding system upon reduction of $\left[\mathrm{Fe}^{\mathrm{III}}(\mathrm{CN})_{6}\right]^{3-}$ to $\left[\mathrm{Fe}^{\mathrm{II}}(\mathrm{CN})_{6}\right]^{4-}[4,21,23]$, while the insertion of $\mathrm{Na}^{+}$to small site (such as $24 \mathrm{~d}$ ) plays a more prominent role to lattice expansion. As a result, the change of the unit cell volume after the insertion of $\mathrm{K}^{+}$is 
around 3\%, smaller than $\mathrm{Na}^{+}$(around 6\%) [16]. Ex-situ Raman spectroscopy (Fig. 5d) illustrates the valance state change of Fe. The ex-situ Raman spectroscopy of fully discharged electrode shows three peaks at 2150, 2127 and $2080 \mathrm{~cm}^{-1}$ (Fig. 5d, spectrum 5), indicating a total of two ions transfer during the discharge process. Nevertheless, the peak at $2080 \mathrm{~cm}^{-1}$ is not very obvious because the electrode is exposed to air during the Raman testing. Similar phenomenon has been observed by Samain et al [36]. The $v(\mathrm{CN})$ bands shift gradually toward low wave number positions during the discharge process, indicating the redox of $\mathrm{Fe}^{3+}$ and $\mathrm{Fe}^{2+}$ [7].

Fig. 8 show the cycling and rate performances of NKFF-X in $\mathrm{Na}$ half cells. During the charge and discharge at a low current density of $0.1 \mathrm{C}$ (Fig. 8a), the capacity of NKFF-1 slightly decreases from $137.0 \mathrm{mAh} \mathrm{g}^{-1}$ initially to $134.7 \mathrm{mAh} \mathrm{g}^{-1}$ after 30 cycles, while the cycling stability get worse when the $\mathrm{K}$ content decrease. The long cycling stability of NKFF-1 is shown in Fig. $\mathbf{8 b}, \mathbf{9 4 . 0 \%}$ of capacity retention after 120 cycles is excellent compared with other alkali ion rich samples [8, 9, 17]. Unfortunately, the rate performance of potassic samples are relatively poor (as shown in Fig. 8c). The Na and K molar ratio (normalized to Fe content) of NKFF-1 electrode fully discharged at $2 \mathrm{C}$ is 0.19 and 0.47 , respectively (the ratio is 0.12 and 0.87 at 0.1 C). It may result from the low concentration and sluggish kinetics of $\mathrm{K}^{+}$. Fig. 8d shows discharge curves of the NKFF-1/Na half-cell at different current densities, a superior rate capability at the low voltage plateau is contributed by the $\mathrm{Fe}^{\mathrm{HS}}-\mathrm{N}$ couple, as the $\mathrm{K} / \mathrm{Na}$-inserted $\mathrm{FeFe}(\mathrm{CN})_{6}$ behaves more like a metallic system with increased electronic conduction [37]. 
Furthermore, we fabricated $\mathrm{Li}$ half cells to investigate the co-insertion mechanism of $\mathrm{K}^{+}$and $\mathrm{Li}^{+}$. However, only the first charge process (de-intercalation of $\mathrm{K}^{+}$) is similar to $\mathrm{Na}$ half cells (Fig. S4). The rapid capacity fading and gradually uneven plateaus are like the lithium PB cells as reported [5]. It can be attributed to the lower standard redox potential of $\mathrm{Li} / \mathrm{Li}^{+}$than $\mathrm{K} / \mathrm{K}^{+}$, and the replacement of $\mathrm{K}$ by $\mathrm{Li}$. The deposition of $\mathrm{K}$ metal at anode is non-activated. For Na half cells, no $\mathrm{K}$ metal deposits as the potential of $\mathrm{Na} / \mathrm{Na}^{+}$is higher.

\section{Conclusions}

In summary, $\mathrm{Na}_{\mathrm{x}} \mathrm{K}_{\mathrm{y}} \mathrm{FeHCF}$ with different $\mathrm{Na}$ and $\mathrm{K}$ contents are successfully synthesized by a simple co-precipitation process. As a potassium ion-selective material, low concentration of $\mathrm{K}^{+}$is able to reinsert into FeHCF structure in Na half cells. The intercalation sites of $\mathrm{Na}^{+}$are influenced by neighboring $\mathrm{K}^{+}$, so that the potassic samples exhibit two even plateaus. The reversible extraction of $\mathrm{K}^{+}$at $8 \mathrm{c}$ site prevents the phase transition and volumetric expansion, corresponds to a good cycling stability with $94.0 \%$ of capacity retention after 120 cycles. Therefore, the potassium ions play an important role in $\mathrm{FeHCF}$, and make it a promising cathode material for $\mathrm{K}^{+} / \mathrm{Na}^{+}$hybrid ion batteries.

\section{Acknowledgements}

This study was supported by National Science Foundation of China (grant no. 51577175), Hefei Center of Materials Science and Technology (grant no. 
2014FXZY006) and Education Department of Anhui Province (grant no. KJ2014ZD36). We are also grateful to Elementec Ltd in Suzhou.

\section{Appendix A. Supplementary data}

Supplementary data related to this article.

\section{References}

[1] D. Asakura, M. Okubo, Y. Mizuno, T. Kudo, H. Zhou, K. Ikedo, T. Mizokawa, A. Okazawa, N. Kojima, Fabrication of a Cyanide-Bridged Coordination Polymer Electrode for Enhanced Electrochemical Ion Storage Ability, The Journal of Physical Chemistry C 116 (2012) 8364.

[2] A. Eftekhari, Potassium secondary cell based on Prussian blue cathode, Journal of Power Sources $126(2004) 221$.

[3] C.D. Wessells, S.V. Peddada, R.A. Huggins, Y. Cui, Nickel hexacyanoferrate nanoparticle electrodes for aqueous sodium and potassium ion batteries, Nano Letters $11(2011) 5421$.

[4] C.D. Wessells, R.A. Huggins, Y. Cui, Copper hexacyanoferrate battery electrodes with long cycle life and high power, Nature Communications 2 (2011) 550.

[5] N. Imanishi, T. Morikawa, J. Kondo, Y. Takeda, O. Yamamoto, N. Kinugasa, T. Yamagishi, Lithium intercalation behavior into iron cyanide complex as positive electrode of lithium secondary battery, Journal of Power Sources 79 (1999) 215. 
[6] Y. You, X.-L. Wu, Y.-X. Yin, Y.-G. Guo, A zero-strain insertion cathode material of nickel ferricyanide for sodium-ion batteries, Journal of Materials Chemistry A 1 (2013) 14061.

[7] Y. You, X.-L. Wu, Y.-X. Yin, Y.-G. Guo, High-quality Prussian blue crystals as superior cathode materials for room-temperature sodium-ion batteries, Energy \& Environmental Science 7 (2014) 1643.

[8] H.W. Lee, R.Y. Wang, M. Pasta, S.W. Lee, N. Liu, Y. Cui, Manganese hexacyanomanganate open framework as a high-capacity positive electrode material for sodium-ion batteries, Nature Communications 5 (2014) 5280.

[9] L. Wang, J. Song, R. Qiao, L.A. Wray, M.A. Hossain, Y.D. Chuang, W. Yang, Y. Lu, D. Evans, J.J. Lee, S. Vail, X. Zhao, M. Nishijima, S. Kakimoto, J.B. Goodenough, Rhombohedral prussian white as cathode for rechargeable sodium-ion batteries, Journal of the American Chemical Society 137 (2015) 2548.

[10]P. Arora, R.E. White, Capacity Fade Mechanisms and Side Reactions in Lithium-Ion Batteries, Journal of The Electrochemical Society 145 (1998) 3647.

[11] C.M. Kareis, S.H. Lapidus, J.H. Her, P.W. Stephens, J.S. Miller, Non-Prussian blue structures and magnetic ordering of $\mathrm{Na} 2 \mathrm{Mn}(\mathrm{II})[\mathrm{Mn}(\mathrm{II})(\mathrm{CN}) 6]$ and $\mathrm{Na} 2 \mathrm{Mn}(\mathrm{II})[\mathrm{Mn}(\mathrm{II})(\mathrm{CN}) 6] .2 \mathrm{H} 2 \mathrm{O}$, Journal of the American Chemical Society 134 (2012) 2246.

[12] J.H. Her, P.W. Stephens, C.M. Kareis, J.G. Moore, K.S. Min, J.W. Park, G. Bali, B.S. Kennon, J.S. Miller, Anomalous non-Prussian blue structures and magnetic 
ordering of $\mathrm{K}(2) \mathrm{Mn}(\mathrm{II})[\mathrm{Mn}(\mathrm{II})(\mathrm{CN})(6)]$ and $\mathrm{Rb}(2) \mathrm{Mn}(\mathrm{II})[\mathrm{Mn}(\mathrm{II})(\mathrm{CN})(6)]$, Inorganic Chemistry 49 (2010) 1524.

[13] L. Wang, Y. Lu, J. Liu, M. Xu, J. Cheng, D. Zhang, J.B. Goodenough, A superior low-cost cathode for a Na-ion battery, Angewandte Chemie International Edition 52 (2013) 1964.

[14] Y. Moritomo, T. Matsuda, Y. Kurihara, J. Kim, Cubic-Rhombohedral Structural Phase Transition in $\mathrm{Na} 1.32 \mathrm{Mn}[\mathrm{Fe}(\mathrm{CN}) 6] 0.83 \cdot 3.6 \mathrm{H} 2 \mathrm{O}$, Journal of the Physical Society of Japan 80 (2011) 074608.

[15] X. Wu, W. Deng, J. Qian, Y. Cao, X. Ai, H. Yang, Single-crystal FeFe(CN)6 nanoparticles: a high capacity and high rate cathode for Na-ion batteries, Journal of Materials Chemistry A 1 (2013) 10130.

[16] C. Ling, J. Chen, F. Mizuno, First-Principles Study of Alkali and Alkaline Earth Ion Intercalation in Iron Hexacyanoferrate: The Important Role of Ionic Radius, The Journal of Physical Chemistry C 117 (2013) 21158.

[17] Y. Liu, Y. Qiao, W. Zhang, Z. Li, X. Ji, L. Miao, L. Yuan, X. Hu, Y. Huang, Sodium storage in Na-rich NaxFeFe(CN)6 nanocubes, Nano Energy 12 (2015) 386.

[18] X. Sun, V. Duffort, L.F. Nazar, Prussian Blue Mg $\square$ Li Hybrid Batteries, Advanced Science 3 (2016) 1600044.

[19] D.M. Kim, Y. Kim, D. Arumugam, S.W. Woo, Y.N. Jo, M.S. Park, Y.J. Kim, N.S. Choi, K.T. Lee, Co-intercalation of $\mathrm{Mg}(2+)$ and $\mathrm{Na}(+)$ in $\mathrm{Na}(0.69) \mathrm{Fe} 2(\mathrm{CN}) 6$ as a High-Voltage Cathode for Magnesium Batteries, ACS Appl Mater Interfaces 8 (2016) 8554. 
[20] X. Wu, C. Wu, C. Wei, L. Hu, J. Qian, Y. Cao, X. Ai, J. Wang, H. Yang, Highly Crystallized $\mathrm{Na} 2 \mathrm{CoFe}(\mathrm{CN}) 6$ with Suppressed Lattice Defects as Superior Cathode Material for Sodium-Ion Batteries, ACS Applied Materials \& Interfaces 8 (2016) 5393.

[21] D.O. Ojwang, J. Grins, D. Wardecki, M. Valvo, V. Renman, L. Haggstrom, T. Ericsson, T. Gustafsson, A. Mahmoud, R.P. Hermann, G. Svensson, Structure Characterization and Properties of K-Containing Copper Hexacyanoferrate, Inorganic Chemistry 55(2016) 5924.

[22] L. Samain, F. Grandjean, G.J. Long, P. Martinetto, P. Bordet, D. Strivay, Relationship between the Synthesis of Prussian Blue Pigments, Their Color, Physical Properties, and Their Behavior in Paint Layers, The Journal of Physical Chemistry C 117 (2013) 9693.

[23] A. Dostal, G. Kauschka, S.J. Reddy, F. Scholz, Lattice contractions and expansions accompanying the electrochemical conversions of Prussian blue and the reversible and irreversible insertion of rubidium and thallium ions, Journal of Electroanalytical Chemistry 406 (1996) 155.

[24] J. Song, L. Wang, Y. Lu, J. Liu, B. Guo, P. Xiao, J.J. Lee, X.Q. Yang, G. Henkelman, J.B. Goodenough, Removal of interstitial H2O in hexacyanometallates for a superior cathode of a sodium-ion battery, Journal of the American Chemical Society 137 (2015) 2658-2664. 
[25] J.F. Allen, A.K. Bonnette Jr., Thermal decomposition of Prussian blue: Isotopic labeling with Mössbauer-inactive Fe-56, Journal of Inorganic and Nuclear Chemistry 36 (1973) 1011.

[26] M.J. Piernas-Muñoz, E. Castillo-Martínez, O. Bondarchuk, M. Armand, T. Rojo, Higher voltage plateau cubic Prussian White for Na-ion batteries, Journal of Power Sources 324 (2016) 766.

[27] A.L. Crumbliss, P. S. Lugg, N. Morosoff, Alkali Metal Cation Effects in a Prussian Blue Surface-Modified Electrode, Inorganic Chemistry 23 (1984) 4701.

[28] M. Niro, U. Kisaburo, T. Yasuyuki, Formulation of Stokes' Radii in DMF, DMSO and Propylene Carbonate with Solvent Structure Cavity Size as Parameter, Bulletin of the Chemical Society of Japan 48 (1975) 2253.

[29] Y. Mizuno, M. Okubo, E. Hosono, T. Kudo, H. Zhou, K. Oh-ishi, Suppressed Activation Energy for Interfacial Charge Transfer of a Prussian Blue Analog Thin Film Electrode with Hydrated Ions ( $\mathrm{Li}+, \mathrm{Na}+$, and $\mathrm{Mg} 2+$ ), The Journal of Physical Chemistry C 117 (2013) 10877.

[30] R.F. Aglan, G.G. Mohamed, H.A. Mohamed, Chemically Modified Carbon Paste Electrode for Determination of Cesium Ion by Potentiometric Method, American Journal of Analytical Chemistry 03 (2012) 576.

[31] Z. Gao, X. Zhou, G. Wang, P. Li, Z. Zhao, Potassium ion-selective electrode based on a cobalt(II)-hexacyanoferrate film-modified electrode, Analytica Chimica Acta 244 (1991) 39. 
[32] Y. Tani, H. Eun, Y. Umezawa, A cation selective electrode based on copper(II) and nickel(II) hexacyanoferrates: dual responsemechanisms, selective uptake or adsorption of analyte cations, Electrochimica Acta 43 (1998) 3431.

[33] V. Krishnan, A.L. Xidis, V.D. Neff, Prussian blue solid-state films and membranes as potassium ion-selective electrodes, Analytica Chimica Acta 239 (1990) 7.

[34] Y. Umezawa, P. Bühlmann, K. Umezawa, K. Tohda, S. Amemiya, Potentiometric Selectivity Coefficients of Ion-Selective Electrodes, Pure and Applied Chemistry 72 (2000) 1851.

[35] D. Dedovets, P. Bauduin, J. Causse, L. Girard, O. Diat, Switchable self-assembly of Prussian blue analogs nano-tiles triggered by salt stimulus, Physical chemistry chemical physics 18 (2016) 3188.

[36] L. Samain, B. Gilbert, F. Grandjean, G.J. Long, D. Strivay, Redox reactions in Prussian blue containing paint layers as a result of light exposure, Journal of Analytical Atomic Spectrometry 28 (2013) 524.

[37] Y. Jiang, S. Yu, B. Wang, Y. Li, W. Sun, Y. Lu, M. Yan, B. Song, S. Dou, Prussian Blue@C Composite as an Ultrahigh-Rate and Long-Life Sodium-Ion Battery Cathode, Advanced Functional Materials (2016), doi: 10.1002/adfm.201600747.

\section{Figure captions}


Table 1 Molar metal element ratios of NKFF-X (normalized to the Fe content).

Fig. 1 TEM images of (a) NKFF-1, (b)NKFF-5; HR-TEM images of (c) NKFF-1, (d) NKFF-5.

Fig. 2 (a) XRD patterns and (b) the expanded XRD patterns between $15^{\circ}$ and $20^{\circ}$ of NKFF-X, (c) lattice parameter $(\AA)$ of NKFF-X samples.

Fig. 3 TGA and DTA of (a) NKFF-1, (b) NKFF-2, (c) NKFF-3, (d) NKFF-4, (e) NKFF-5 in flowing $\mathrm{N}_{2}$ at a heating rate of $10{ }^{\circ} \mathrm{C} \min ^{-1}$.

Fig. 4 The first and second galvanostatic charge and discharge profiles of NKFF-1 (a) and NKFF-5 (b) at a current density of $14 \mathrm{~mA} \mathrm{~g}^{-1}(0.1 \mathrm{C})$. (c) Crystal structure of iron hexacyanoferrate (high-spin $\mathrm{Fe}$ is pink, low-spin $\mathrm{Fe}$ is green, $\mathrm{C}$ is gray, $\mathrm{N}$ is blue, intercalated $\mathrm{K}^{+}$is purple, intercalating $\mathrm{Na}^{+}$is yellow and interstitial sites are white). (d) $\mathrm{CV}$ curves of the NKFF-X electrodes from 2.0 to $4.2 \mathrm{~V}$ at a scan rate of $0.1 \mathrm{mV} \mathrm{s}^{-1}$.

Fig. 5 (a) Different states of NKFF-1 during the first discharge and the second charge process. Ex-situ (b) XRD patterns, (c) EDS analysis and (d) Raman spectroscopy at these states.

Fig. 6 Schematic of gathering $\mathrm{K}^{+}$at the surface sites during charge and discharge processes.

Fig. 7 The change of lattice parameter during the discharge/charge process.

Fig. 8 (a) Cycling performances of NKFF-X at $0.1 \mathrm{C}\left(1 \mathrm{C}=140 \mathrm{~mA} \mathrm{~g} \mathrm{~g}^{-1}\right)$. (b) Long-term cycling performance of NKFF-1 at 0.5 C. (c) Rate performance of NKFF-1 and NKFF-5. It was charged at low currents $0.5 \mathrm{C}$ (except $0.1 \mathrm{C}$ and $0.2 \mathrm{C}$ ), and 
discharged at different currents. (d) Discharge curves of the NKFF-1/Na half-cell at different currents. 

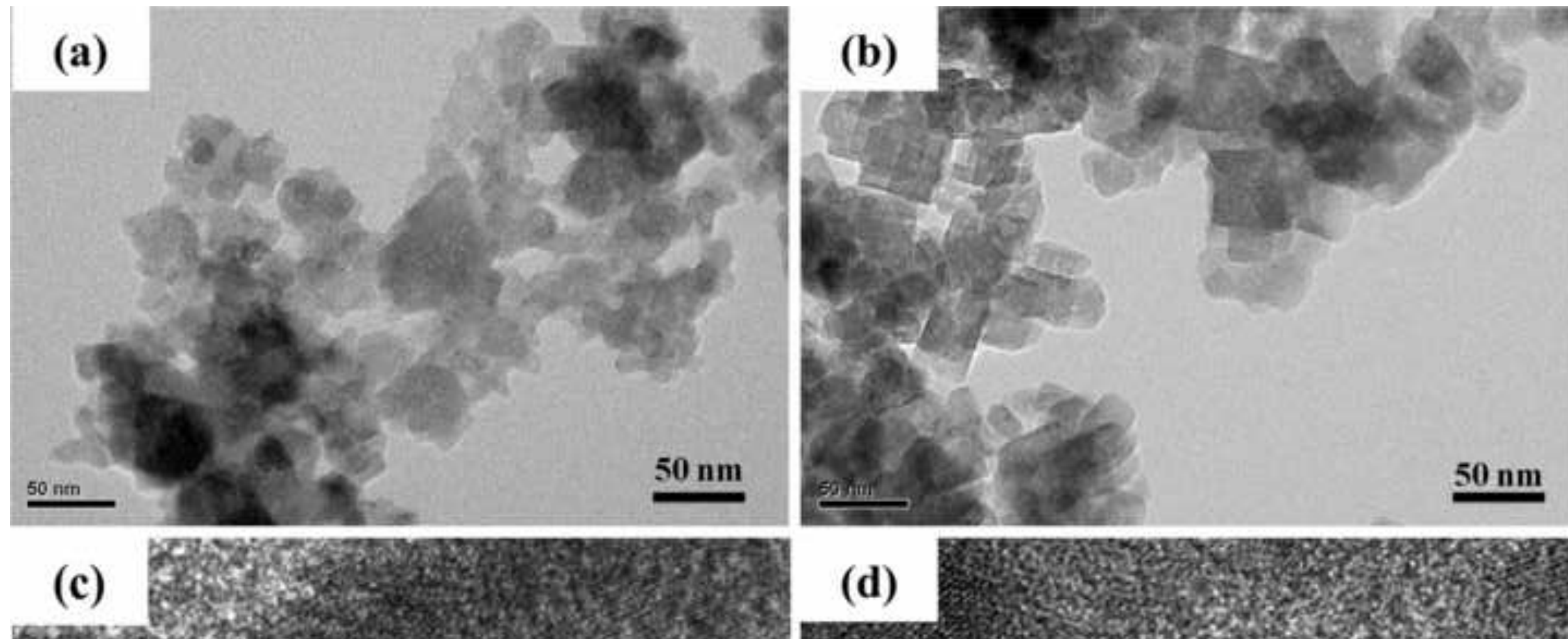

(d)
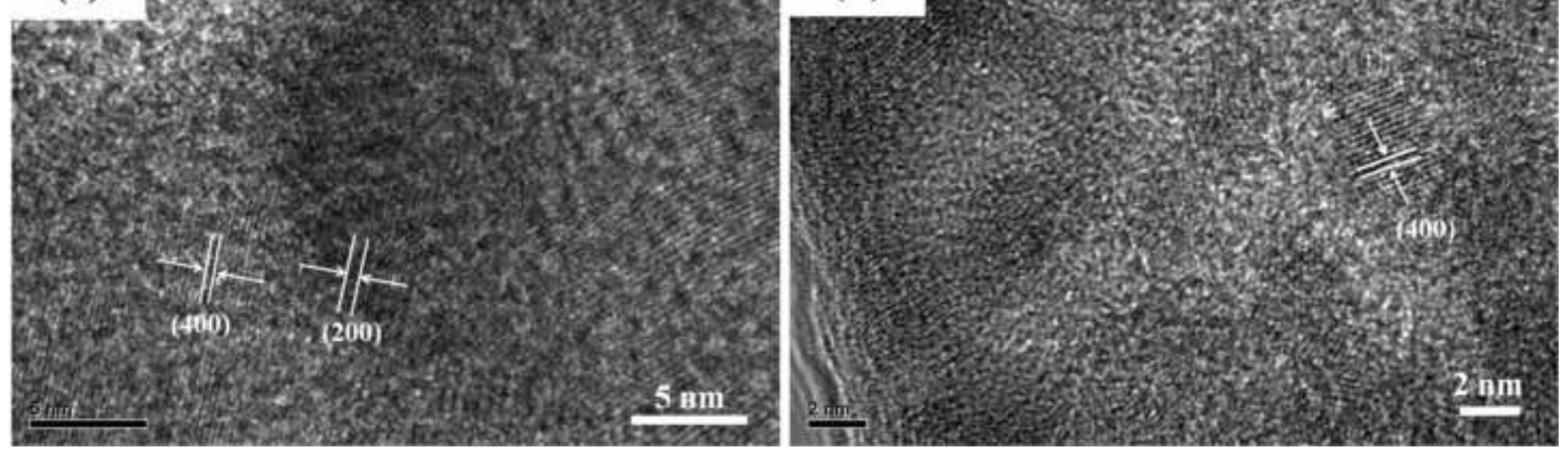


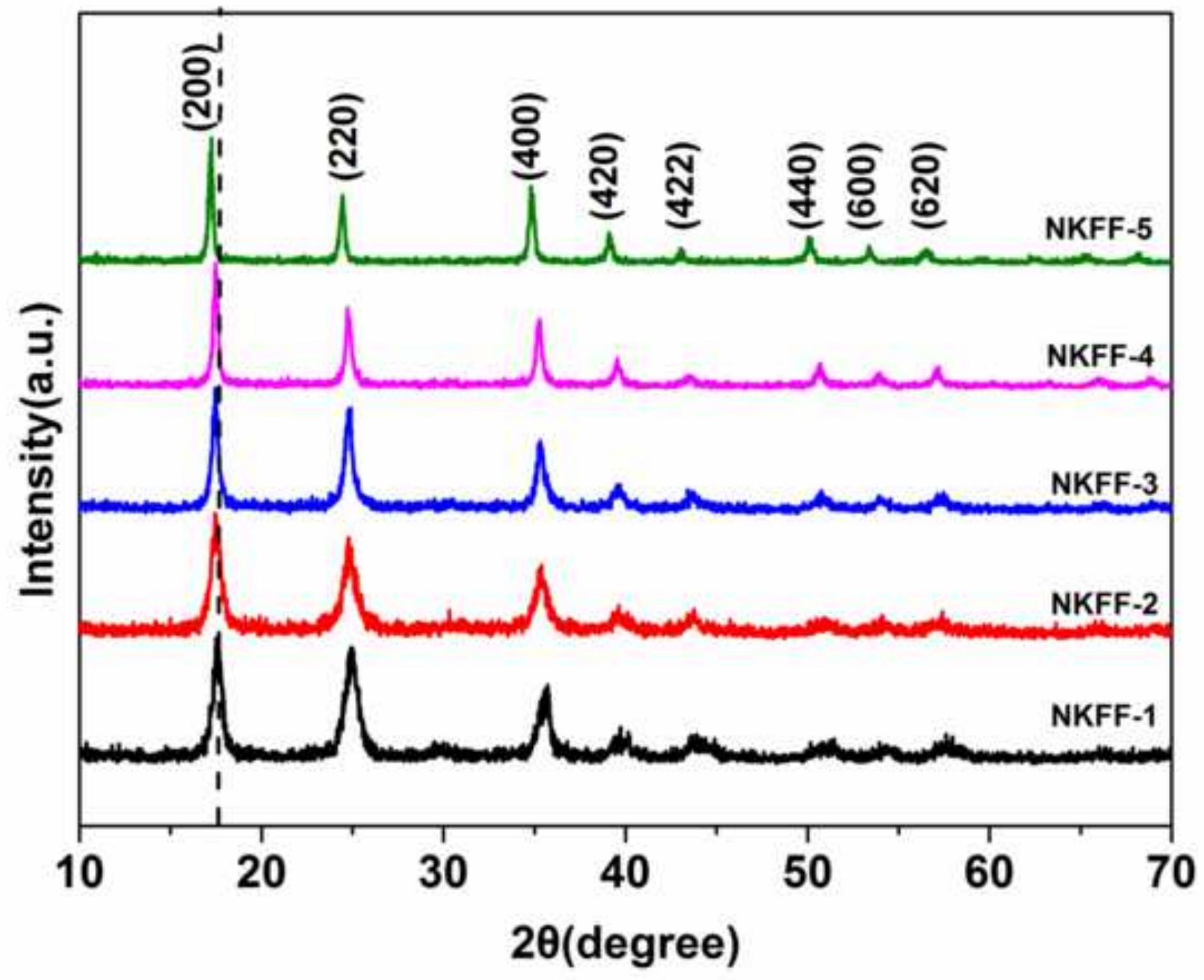




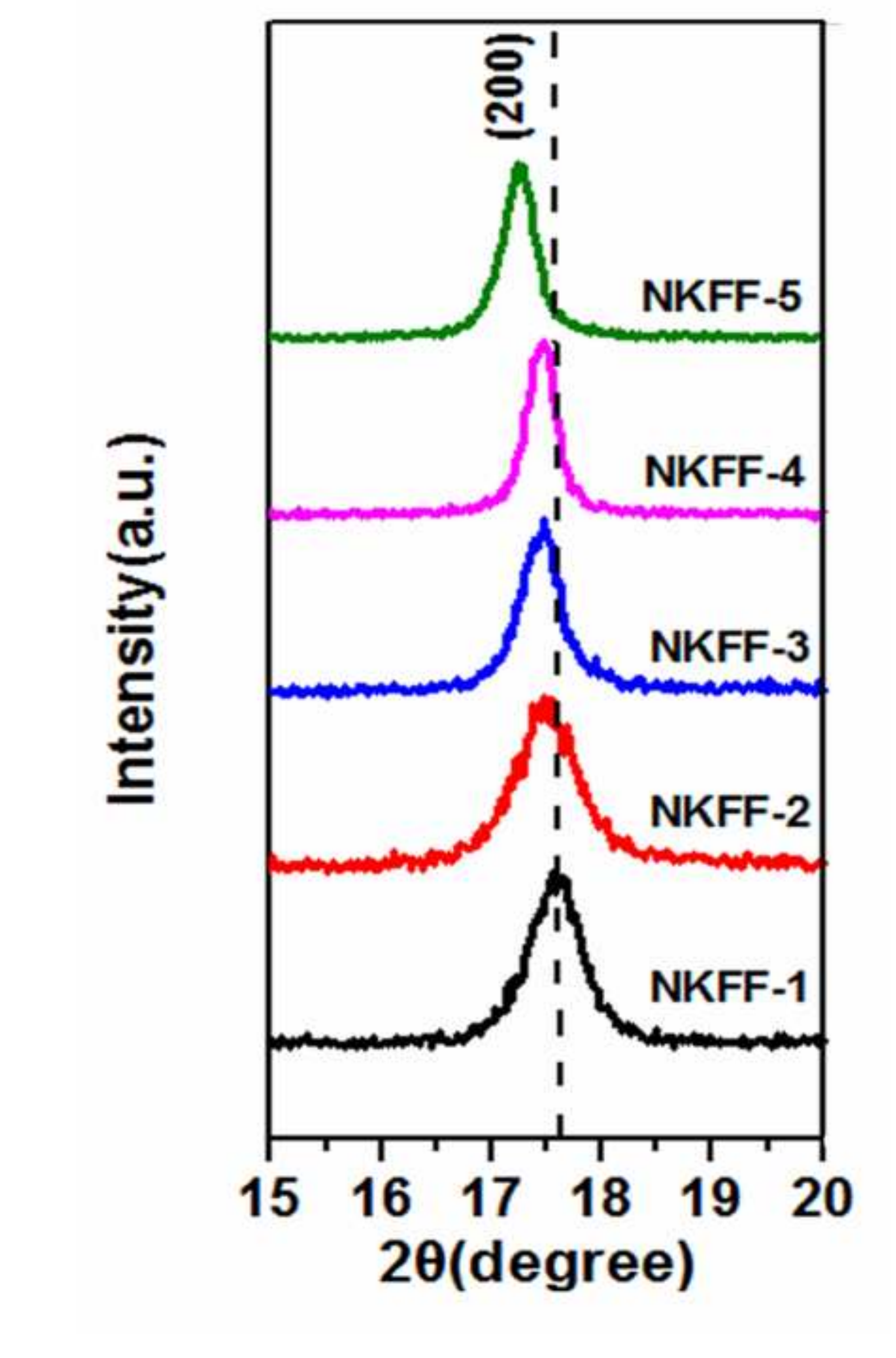

Figure 2(b)

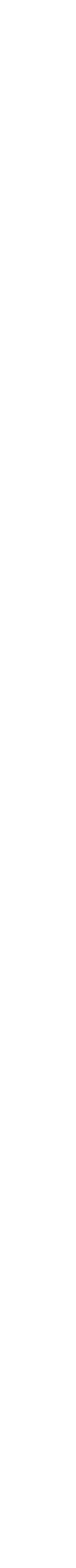

Figure

(b)
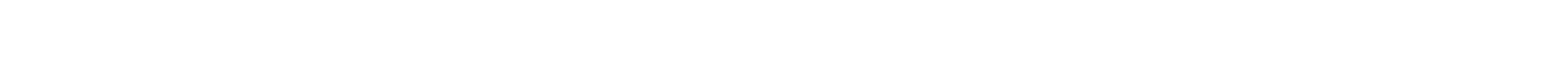

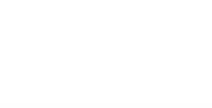

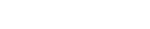

(

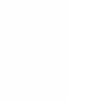


sample

NKFF-1

NKFF-2

NKFF-3

NKFF-4

NKFF-5

$\mathrm{FeFe}(\mathrm{CN})_{6}$

\section{lattice parameter $(\AA)$}

10.13

10.14

10.15

10.16

10.28

10.18 (Ref. 15) 


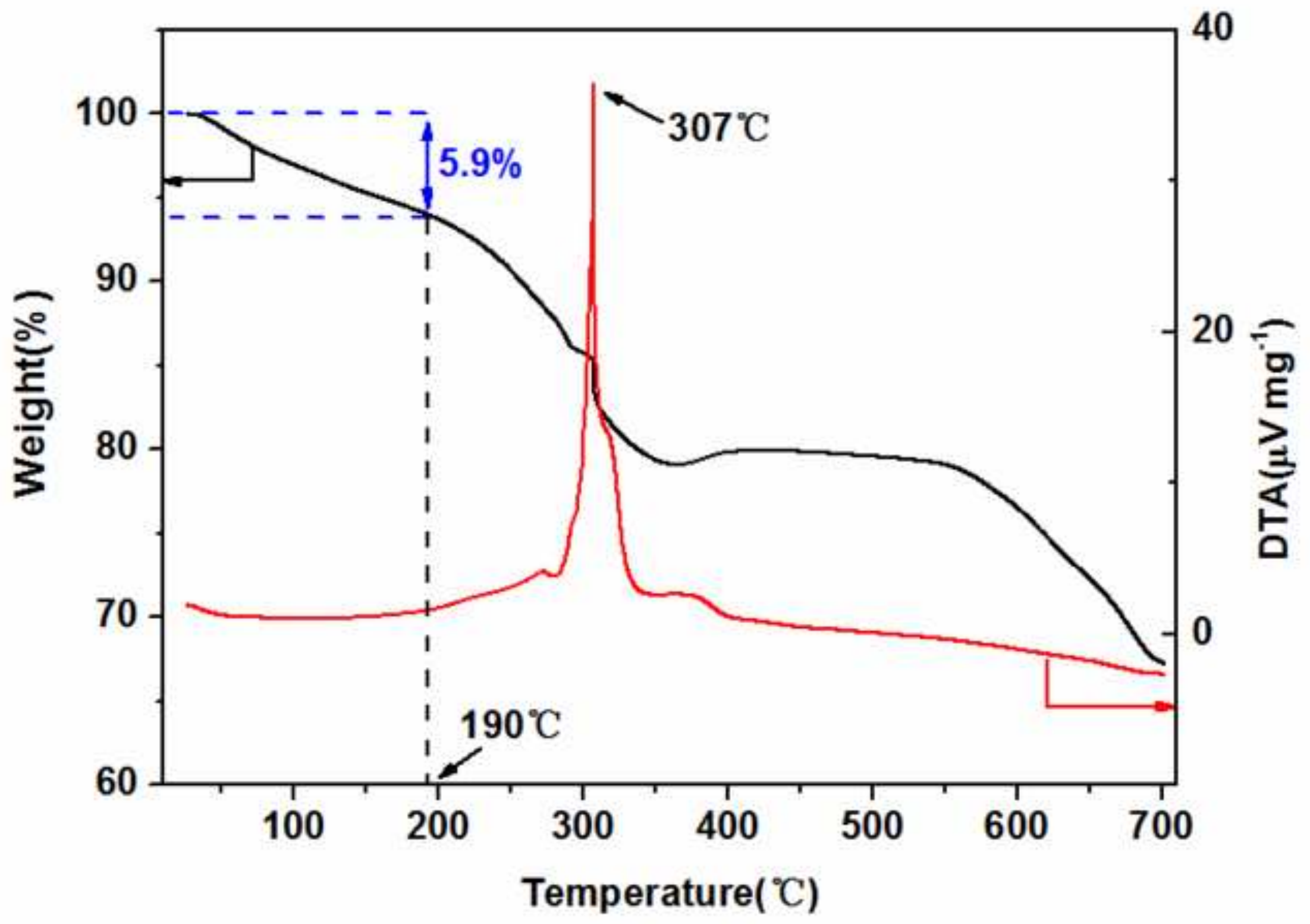




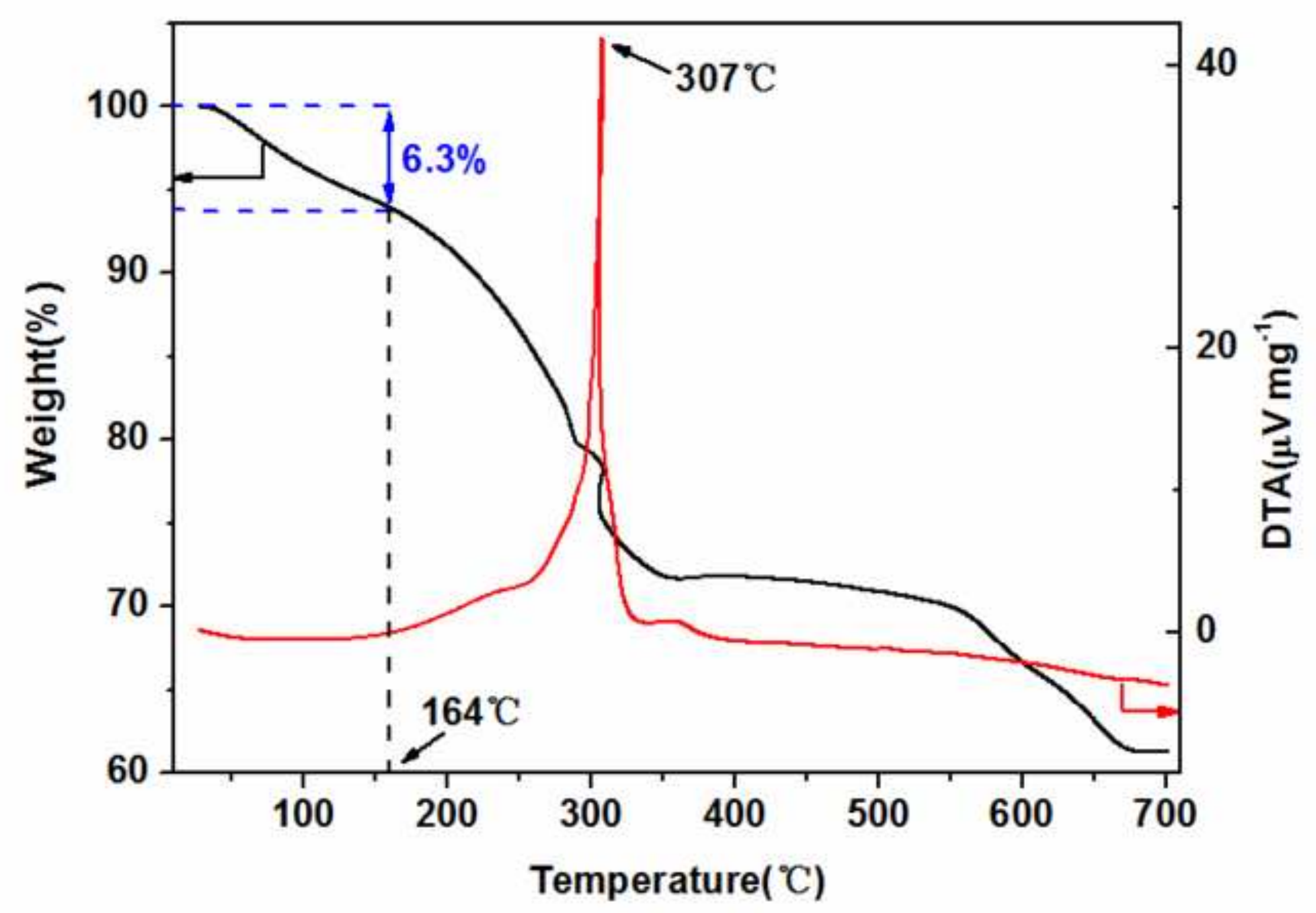




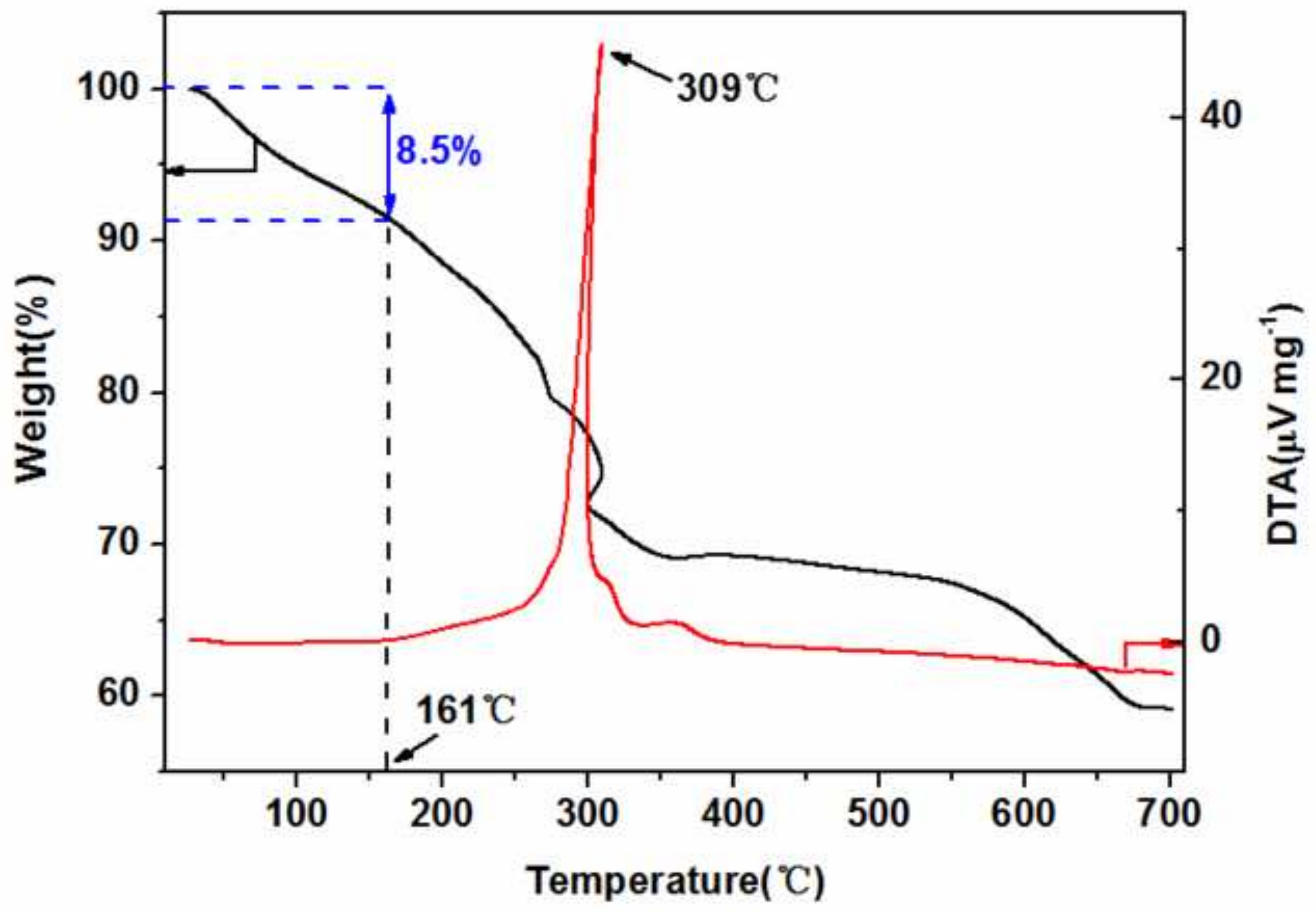




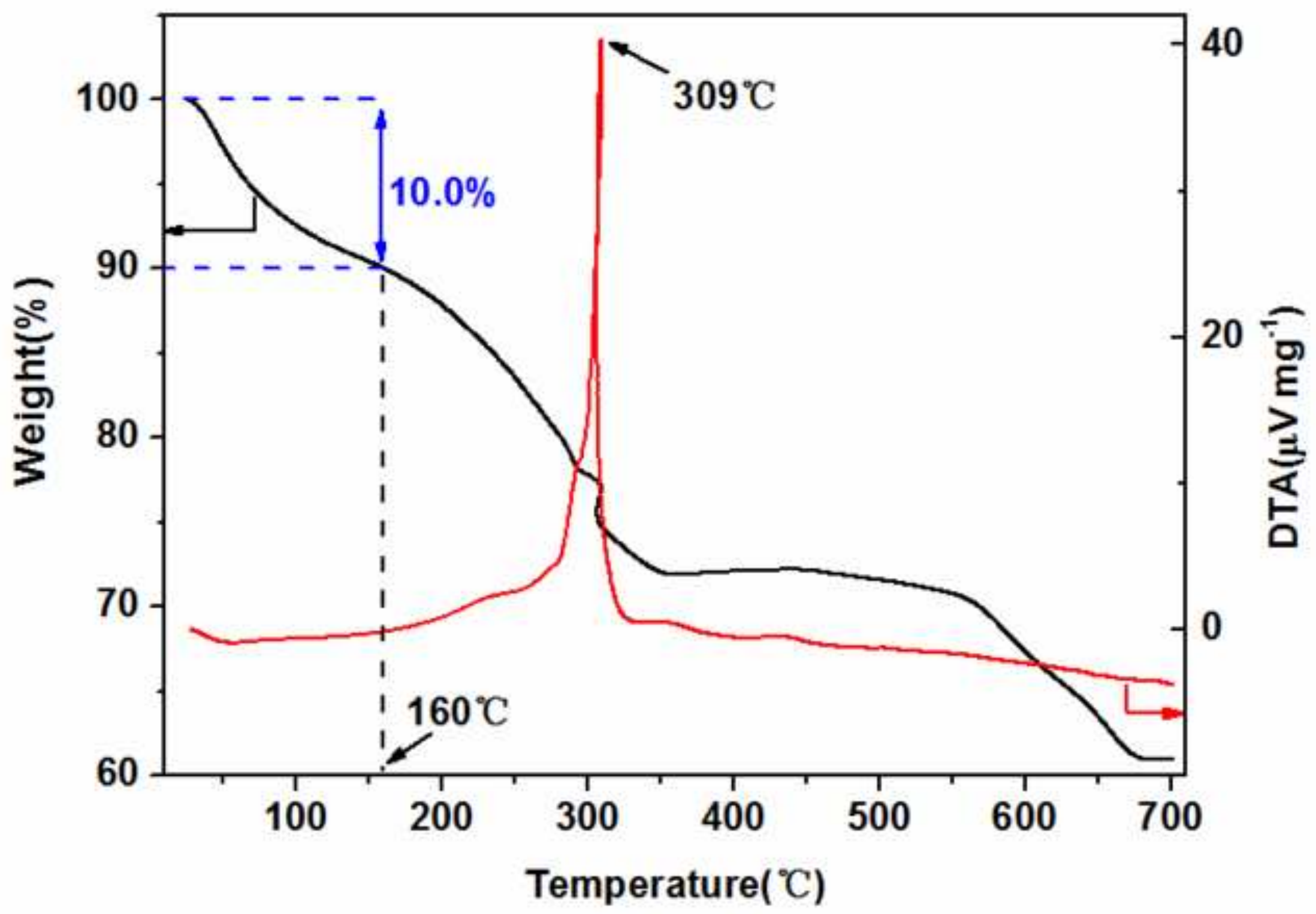




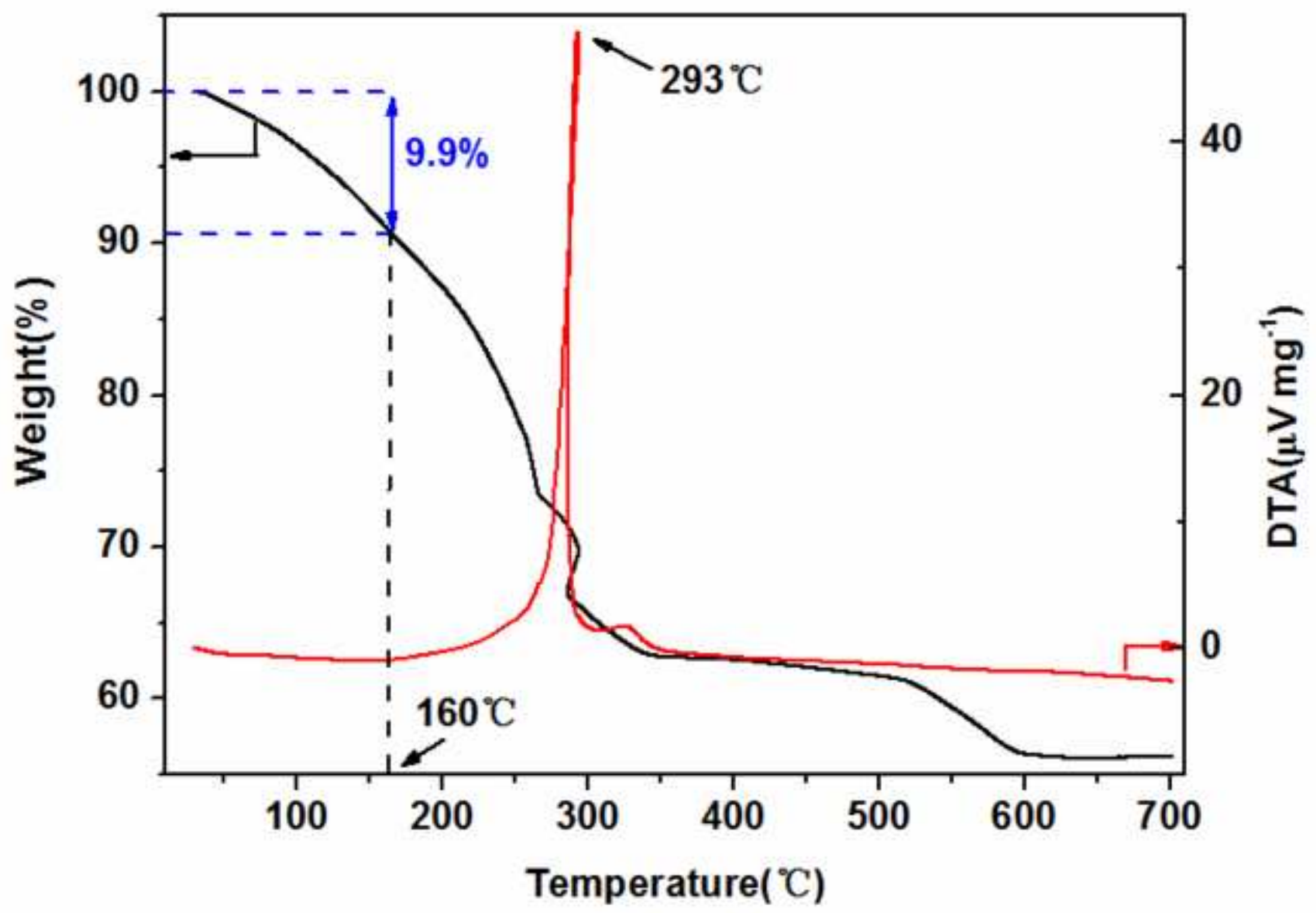


(a)

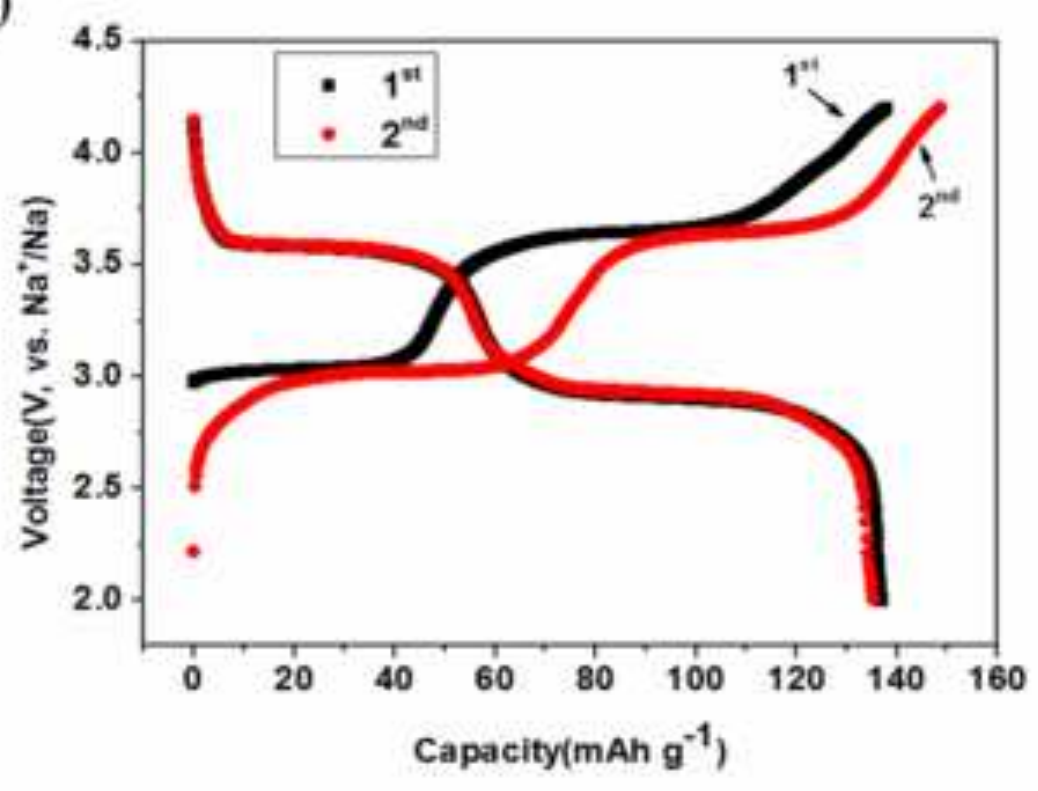

(c)

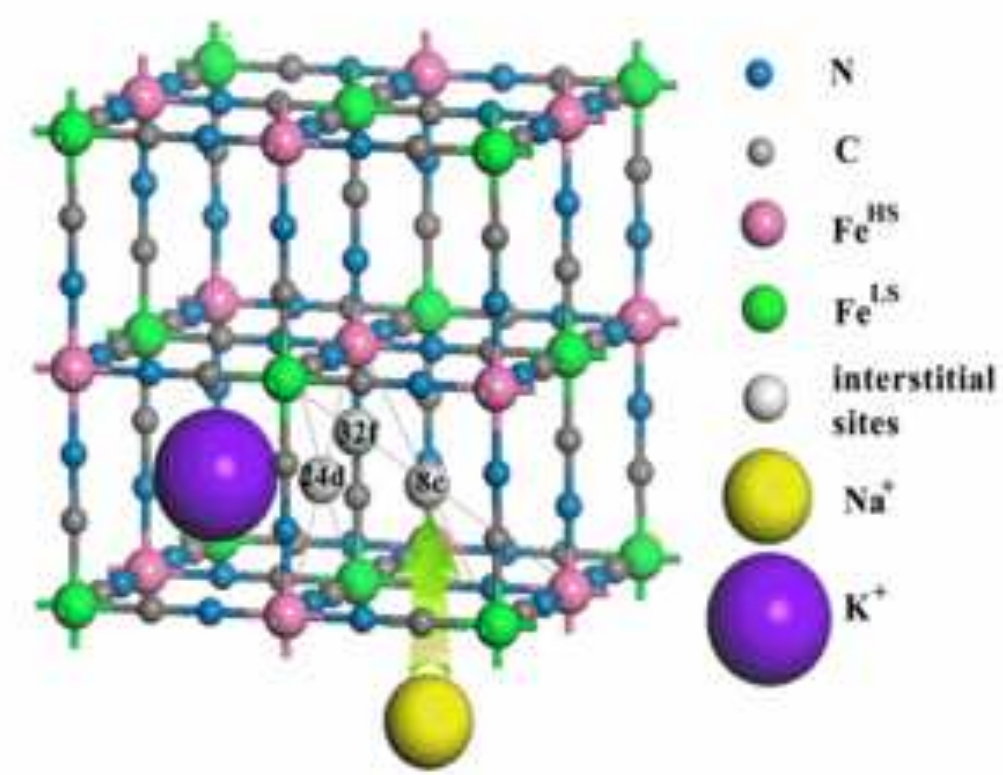

(b)

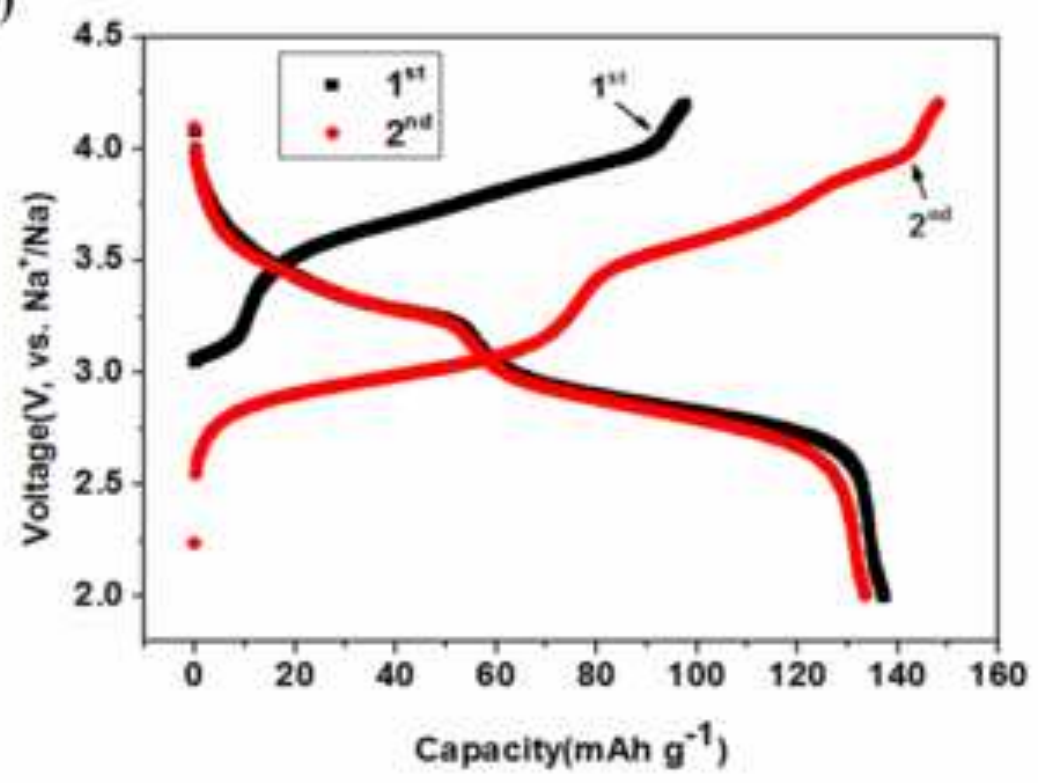

(d)

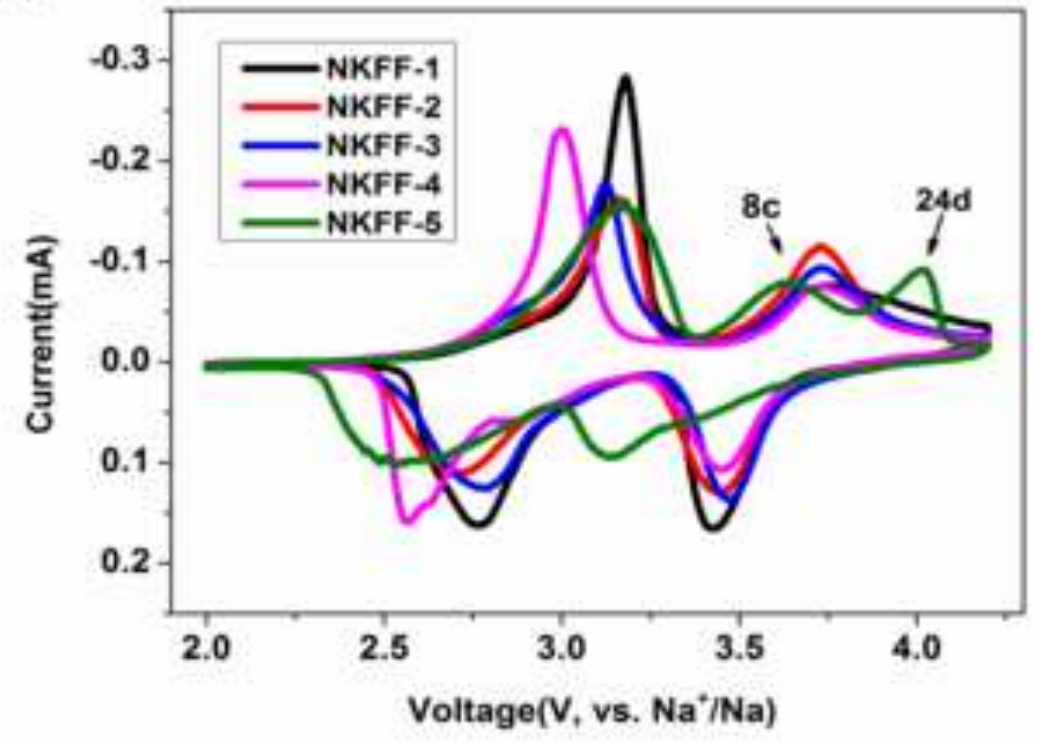


(a)

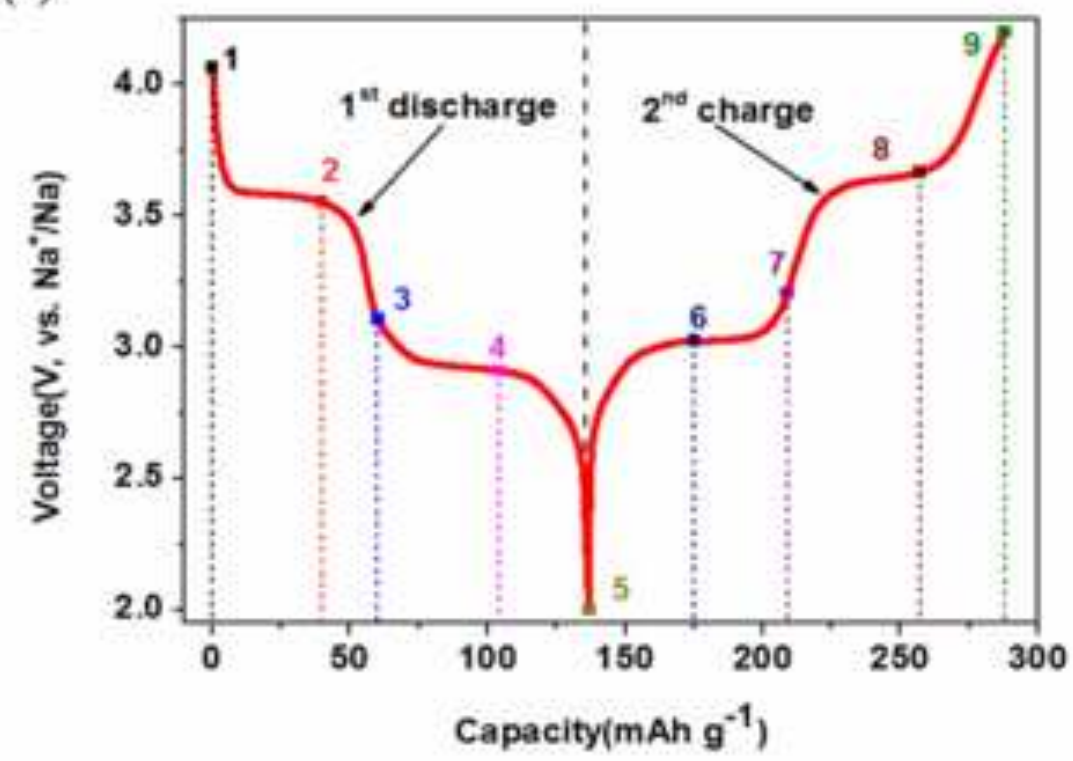

(c)

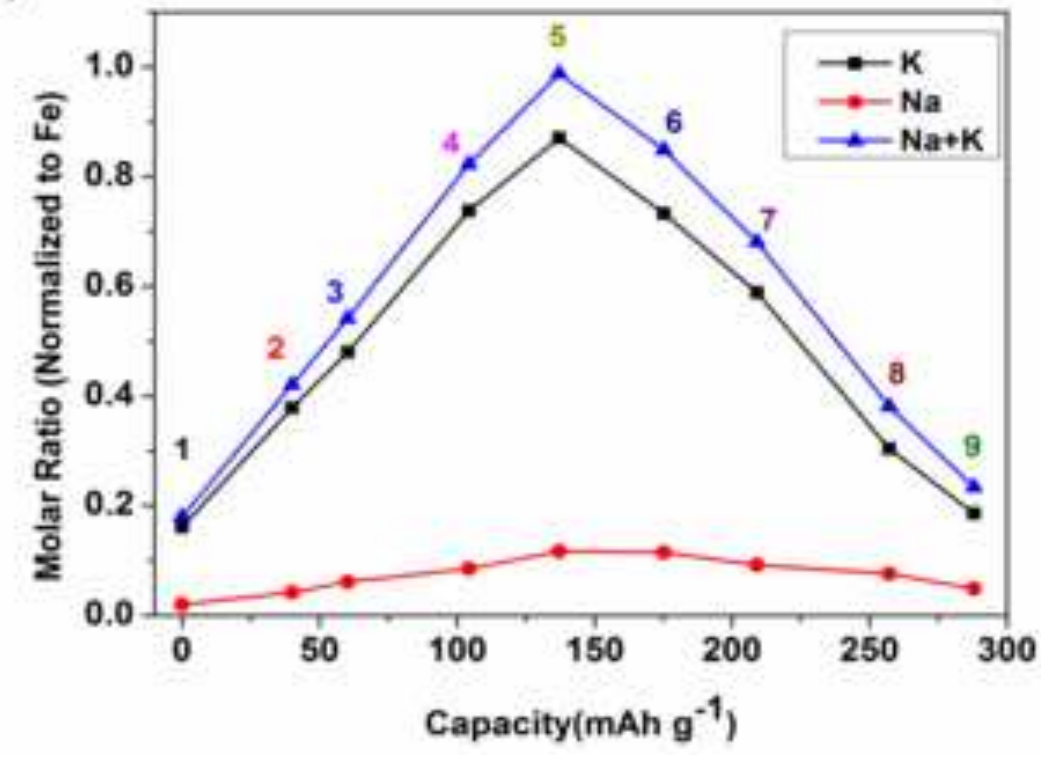

(b)

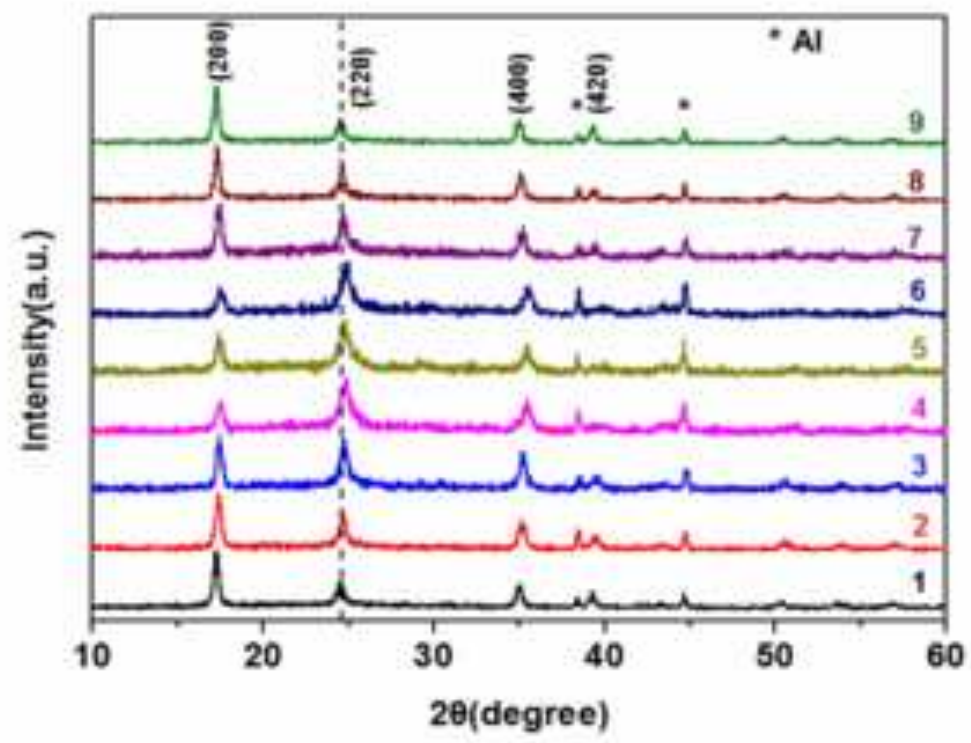

(d)

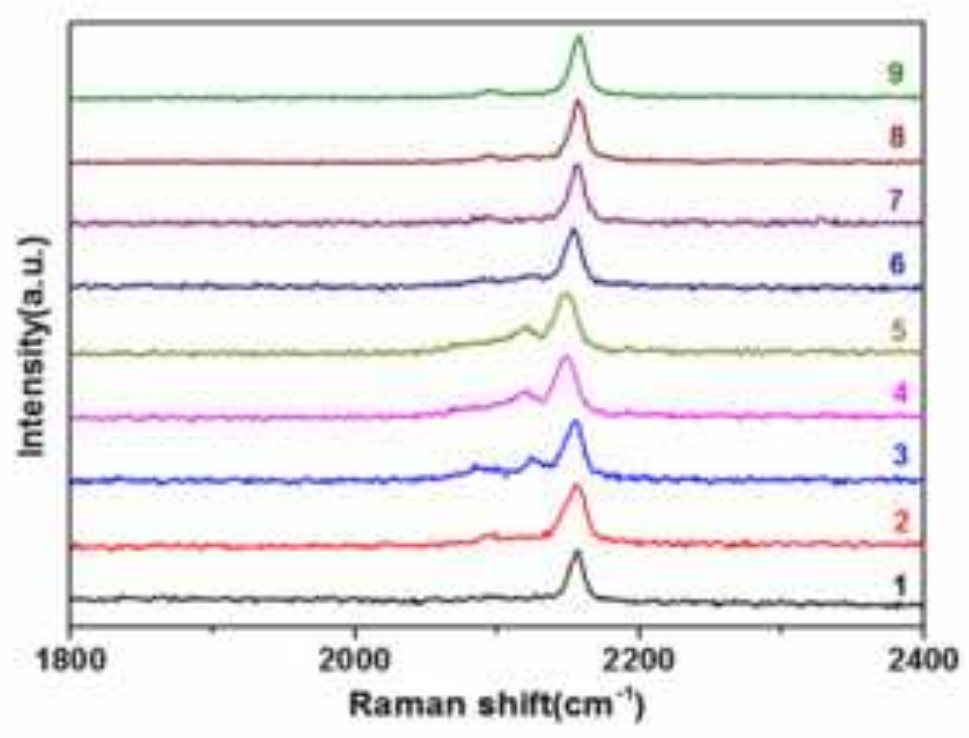




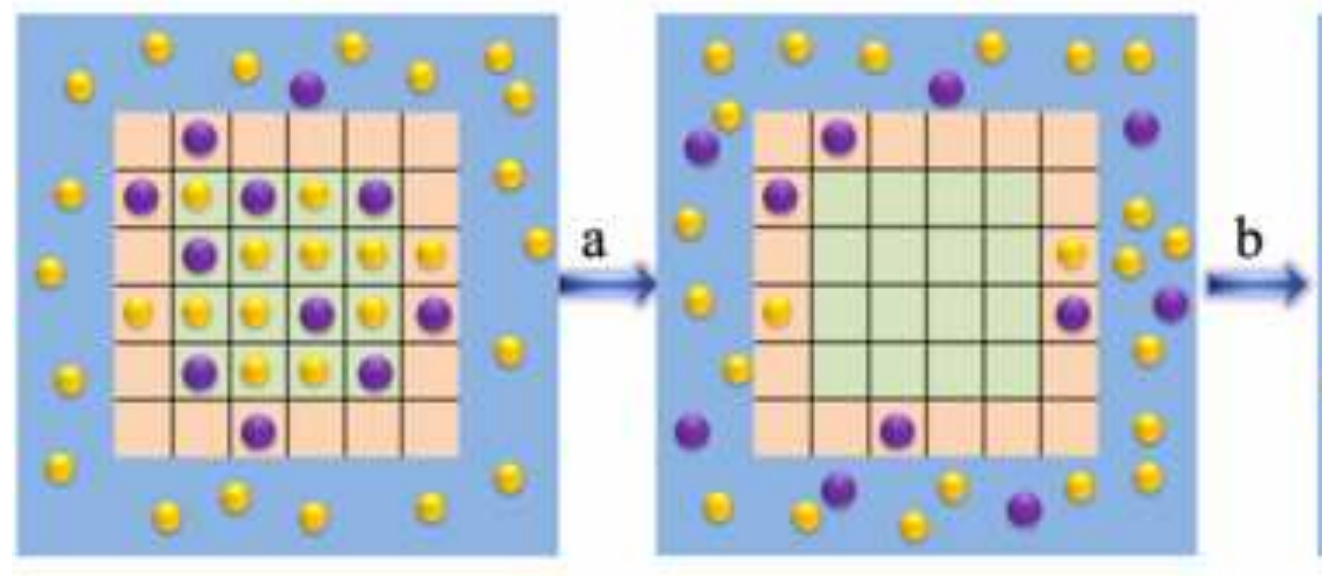

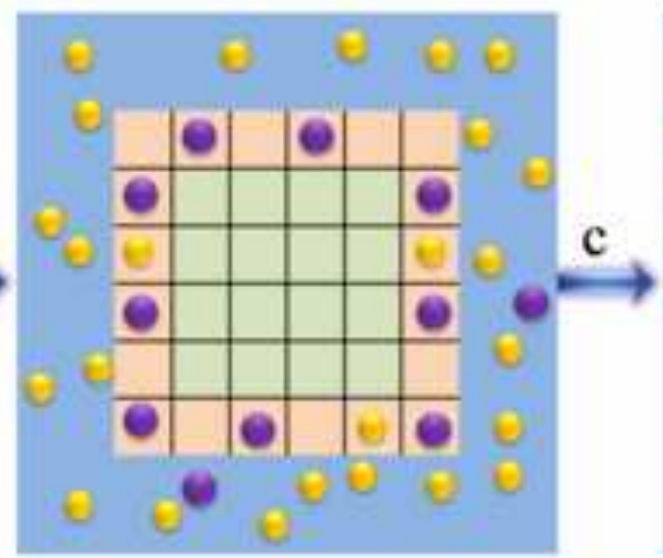

- $\mathrm{K}^{+}$

e $\mathrm{Na}^{+}$

Electrolyte

(a) Extraction

(b) Cation selectivity

(c) Intercalation

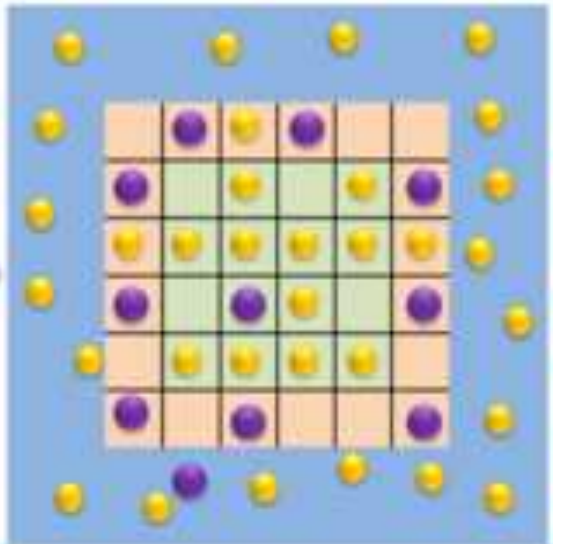




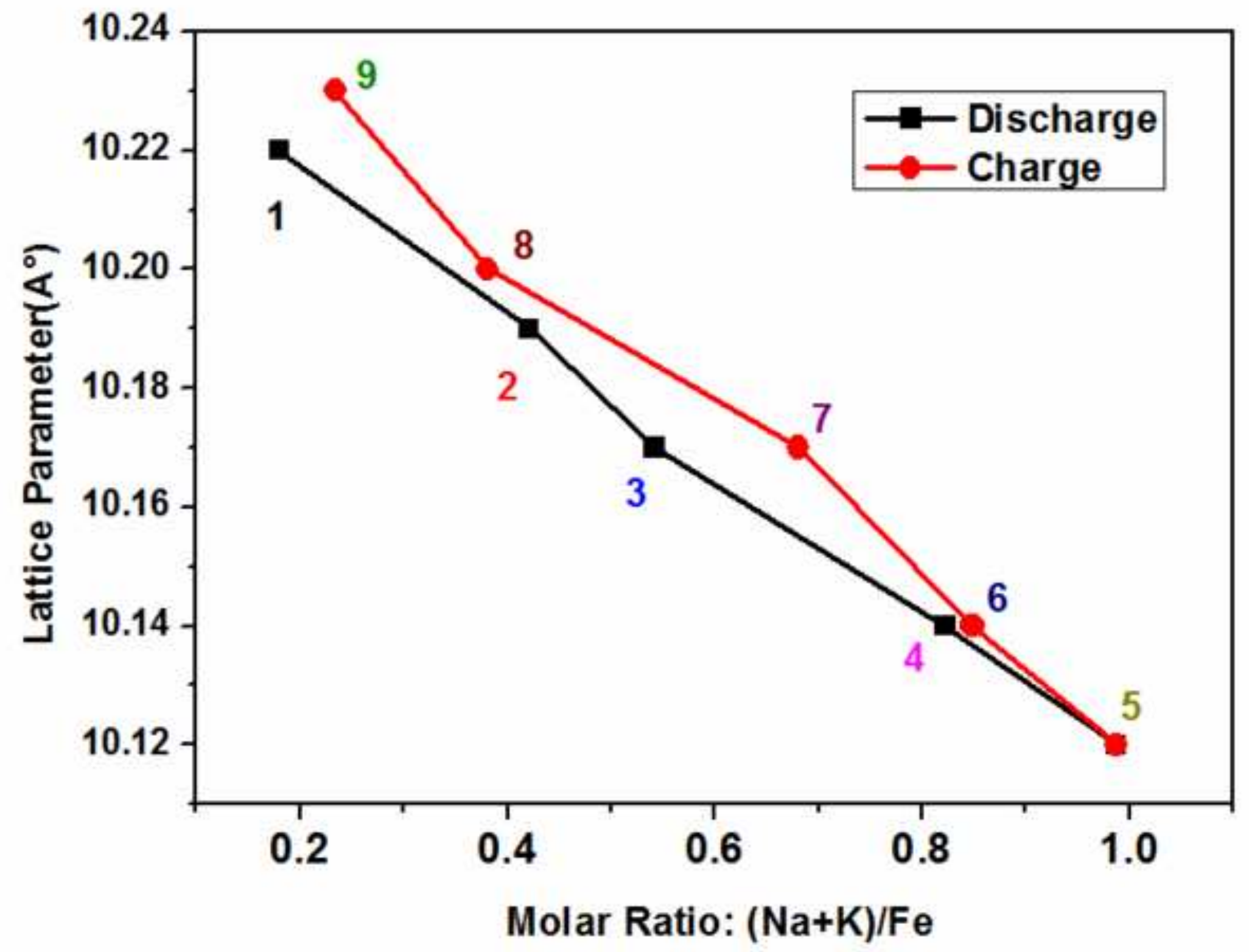


(a)

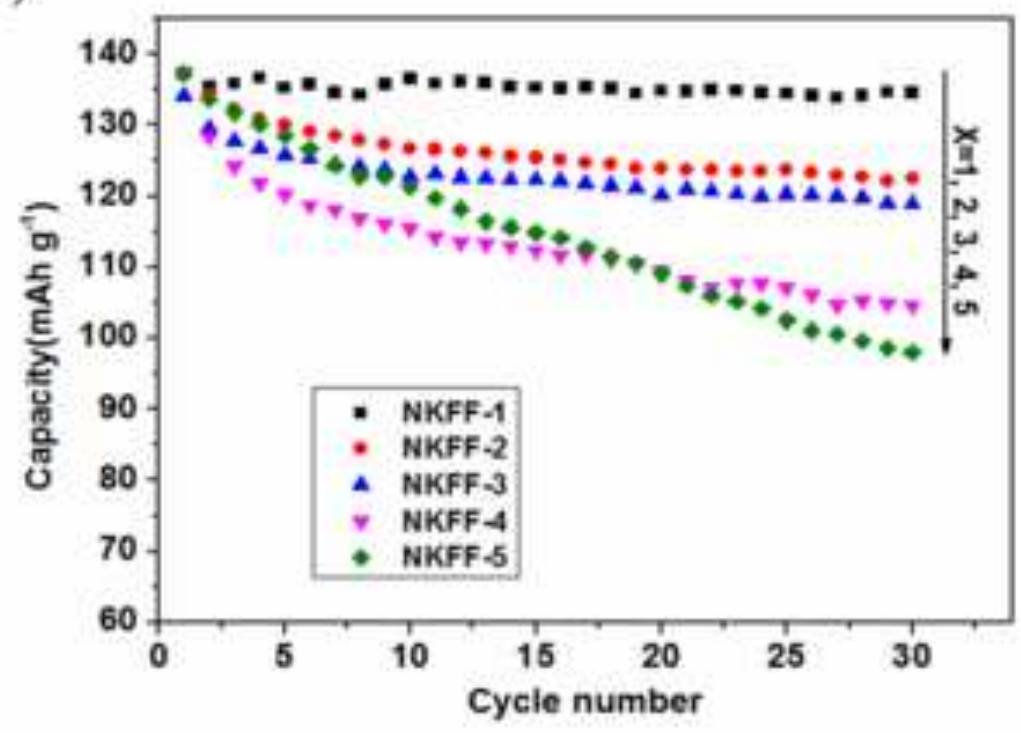

(c)

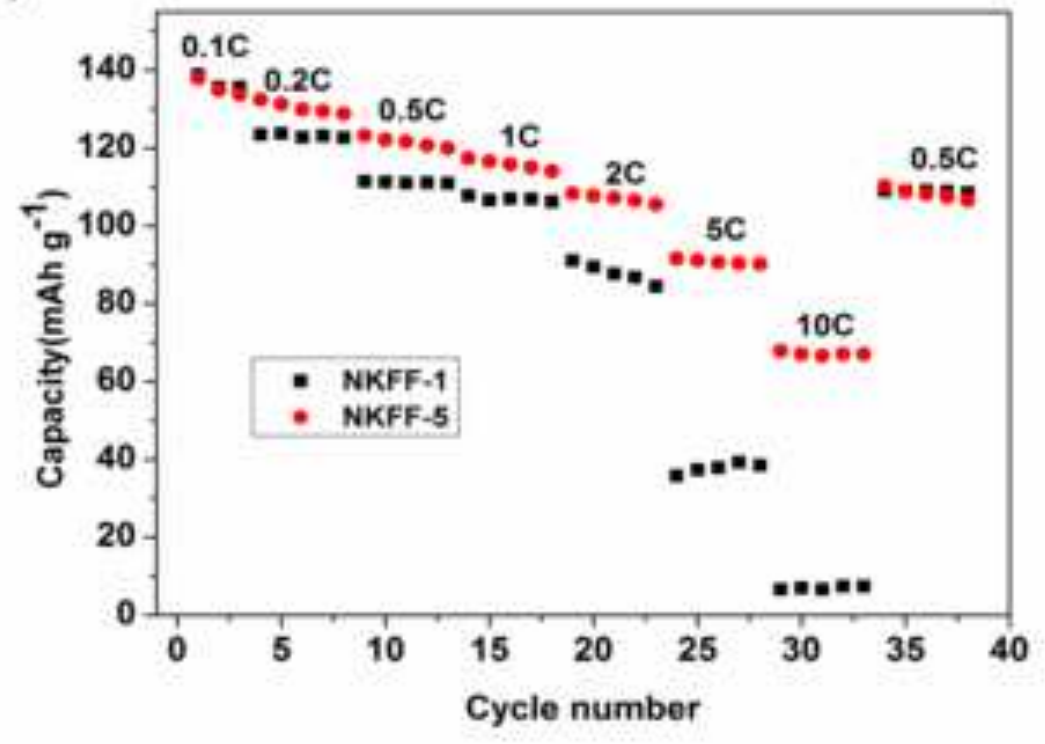

(b)

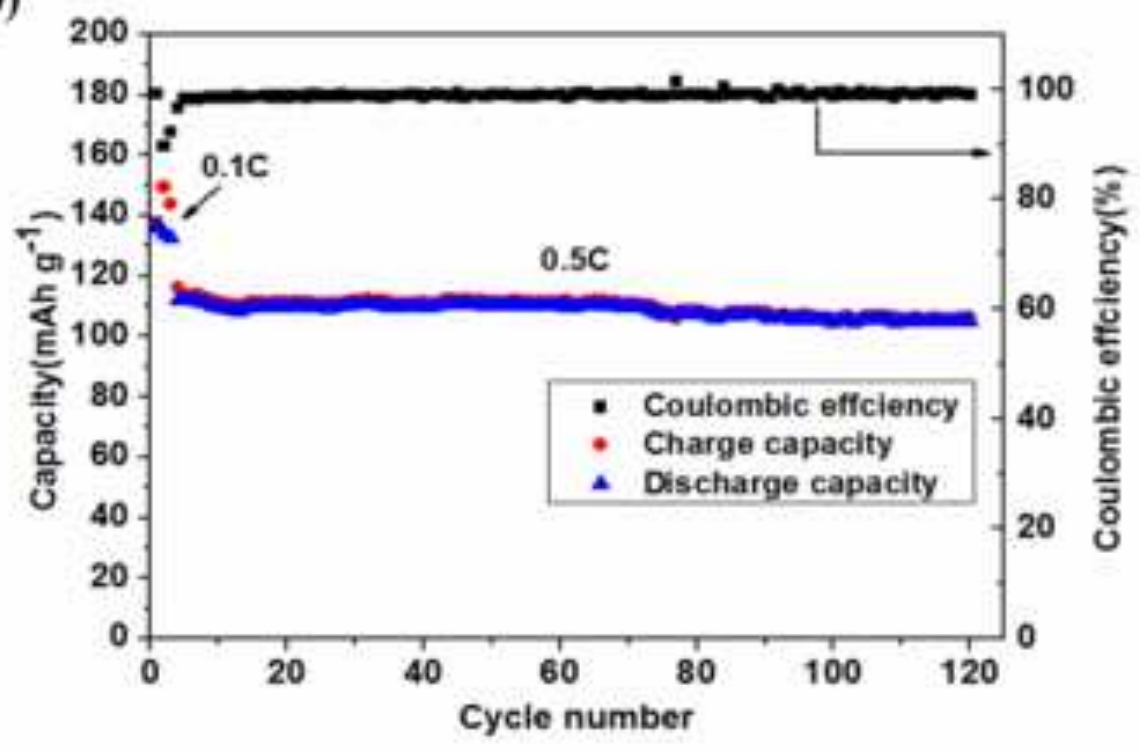

(d)

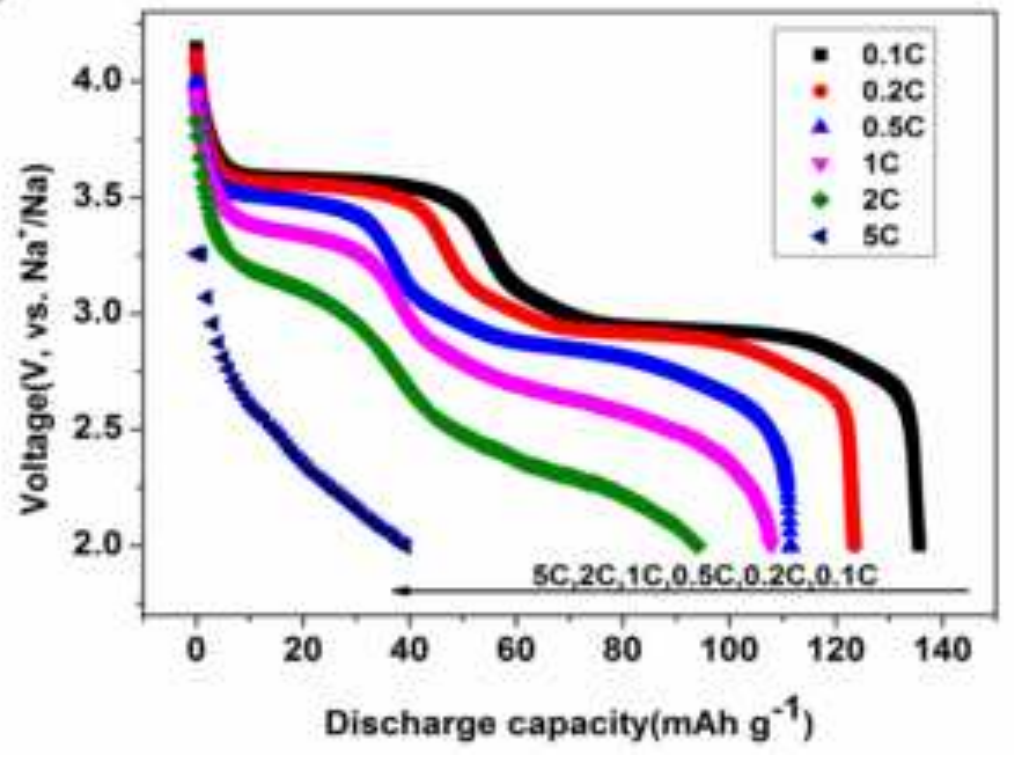


sample

NKFF-1

NKFF-2

NKFF-3

NKFF-4

NKFF-5
$\mathrm{Na}$

0

0.08

0.12

0.17

0.46
K

0.95

0.95

0.77

0.60

0.48

0.35

0.52

0 